\title{
WHAT IS IN AN ORCHID NAME: A TRIBUTE TO THE EARLY NATURALISTS IN COSTA RICA
}

\author{
RUdOLF JENNY \\ Moosweg 9, 3112 Allmendingen, Switzerland \\ rjorchid@gmx.ch
}

\begin{abstract}
The early history of Costa Rican orchidology was deeply influenced by a number of naturalists, mainly European by birth, who dedicated themselves to explore a still virgin country, bringing back from their trips a treasure of species to be apprehended by science. While some of them where just occasional voyagers and explorers, other establish themselves in Costa Rica in a long and fecund relationship, that raised to the birth of a new generation of national naturalists in the first decades of the nineteenth century. Even if their faces are sometimes unknown, their names are linked forever to the orchid that helped to reveal to science and to humanity. What follows, and using as an excuse the name of some orchids, is a brief overview of the life and deeds of some of these early naturalists, as a tribute to their contribution to the development of Costa Rican orchidology.
\end{abstract}

KeY words: History of botany, Costa Rica, Orchidaceae

\section{Pablo Biolley and Telipogon Biolleyi}

Paul (Pablo) Auguste Biolley (Fig. 1A) was born as son of a teacher on $16^{\text {th }}$ of February 1862 in Neuenburg, Switzerland. He studied in Neuenburg and became member of the Société des Sciences Naturelles de Neuchatel and the Société Neuchatelois de Géographie. After graduating, he went as teacher for 2 years to the Netherlands. In 1885 Biolley was invited as teacher and scientist by the Costa Rican government of Bernardo SOTO, he arrived in San Jose in 1886. Together with Henri Francois Pittier, Biolley undertook a number of expeditions through Costa Rica, in 1902 he joined the expedition to the Cocoisland and in 1907 he published results of this trip in the book "Mollusques de la Isla del Coco". His main interest was entomology, but beside insects he also collected plants and made important contributions to the knowledge of the flora of Costa Rica. Biolley was a quiet man, beside his duties as teacher he spent all his free time collecting animals and plants. He married a Costa Rican and got the Costa Rican nationality, for a short period in 1904 he became director of the Instituto Fisico-Geografico. Biolley was not very well accepted as teacher and was a victim of criticism from colleagues and staff; this was certainly one of the reasons why he started to drink. Alcohol finally was the reason of his early death on $16^{\text {th }}$ of January 1908 at the age of only 46. Only a few publications by Biolley are known, beside the one about the molluscs mentioned above, his main works are "Elementos de Historia Natural" from 1887 and "Costa Rica et son avenir" (Costa Rica and its future), published in 1889 in Paris (Fig. 1B).

Telipogon bolleyi (Fig. 1c) was described in 1910 by Rudolf Schlechter in "Feddes Repertorium", the plant was collected in August 1889 in flower by Biolley in forests on the slope of the volcano Barba (no.1340) (Schlechter 1910). Schlechter's drawing of the flower was published by Mansfeld in "Feddes Repertorium" in 1931, the type of the species was lost in the fire of the herbarium in Berlin in 1943 (Mansfeld 1931) (Fig. 1D). From the same collection of Biolley a second, unnamed specimen with the same number 1340 is in the United States National Herbarium (Fig. 2A), originally from the herbarium of the Instituto Fisico-Geografico National Costaricensis, selected first by Calaway H. Dodson in 1983 as neotype and again by Robert L. Dressler in 1999 as the lectotype of Telipogon biolleyi.

\footnotetext{
* This paper was prepared in the framework of the celebration of Lankester Botanical Garden's $40^{\text {th }}$ anniversary.
} 


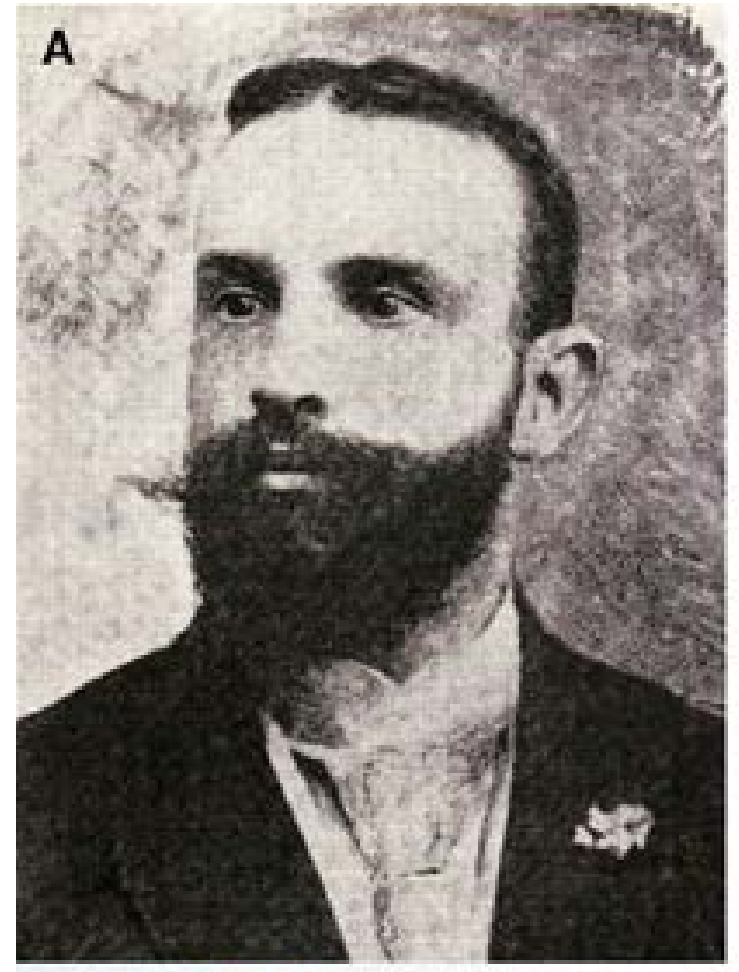

\section{B}

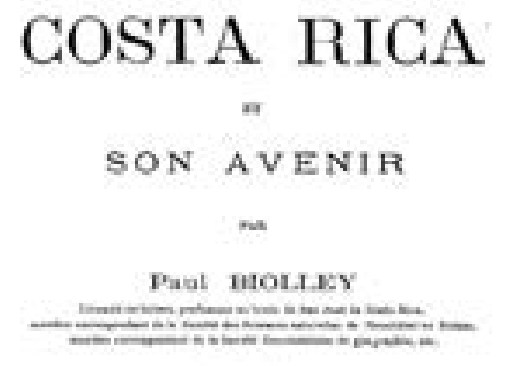

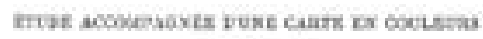

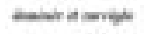

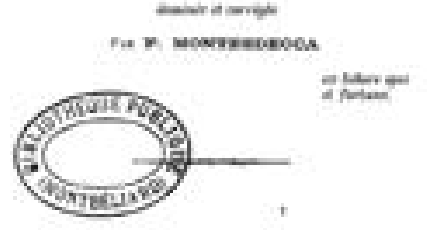

Pails

A. CIAND. LIBEAIRE-BDITEK

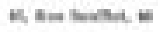

16.

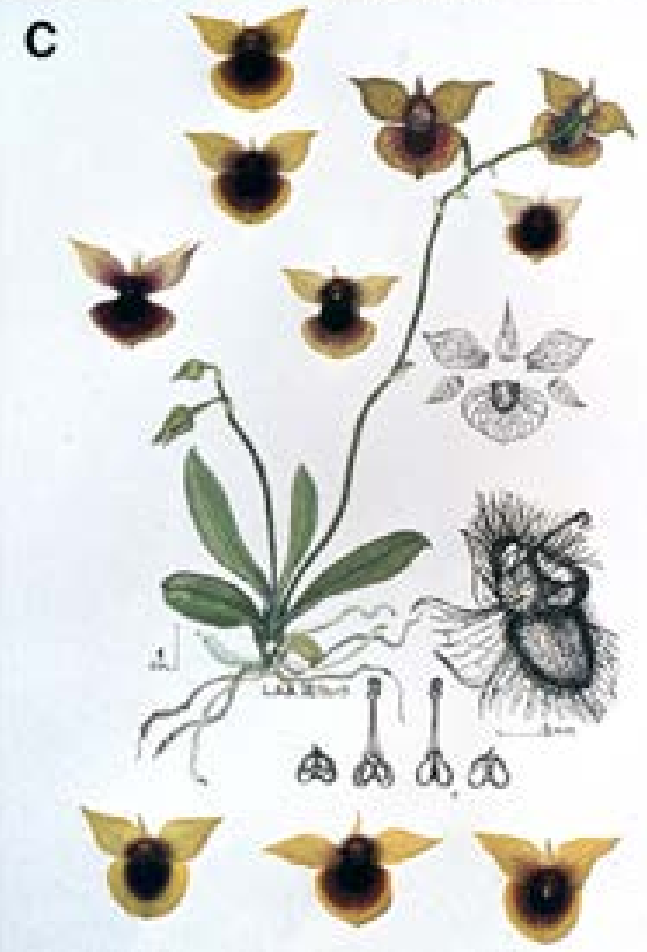

D

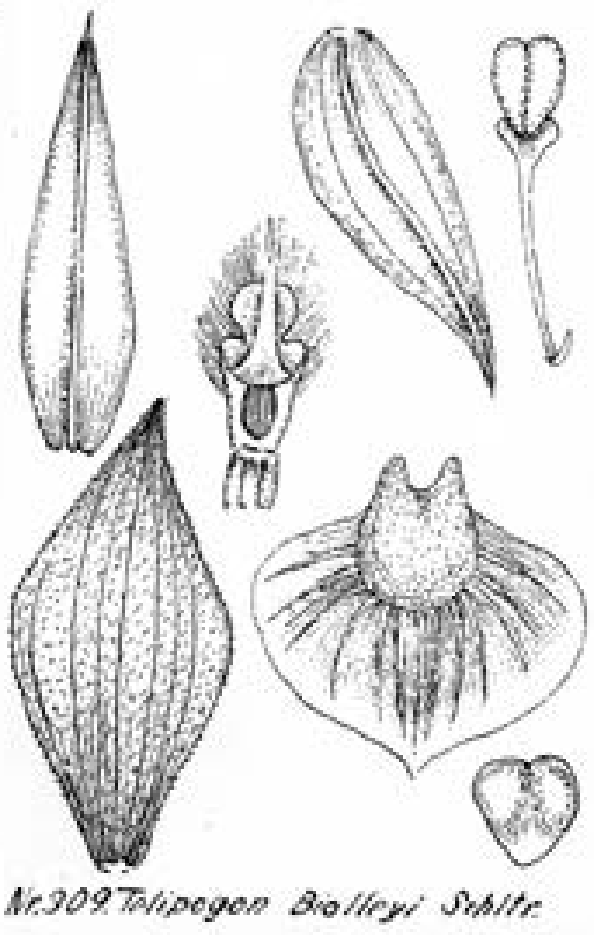

Figure 1. A - Portrait of Pablo Biolley. B - Frontispiece of Biolley's "Costa Rica and son venir", Paris 1889.

C - Telipogon biolleyi, illustrated by Lothar Braas. D - Telipogon biolleyi, from the original sketch by R. Schlechter. 


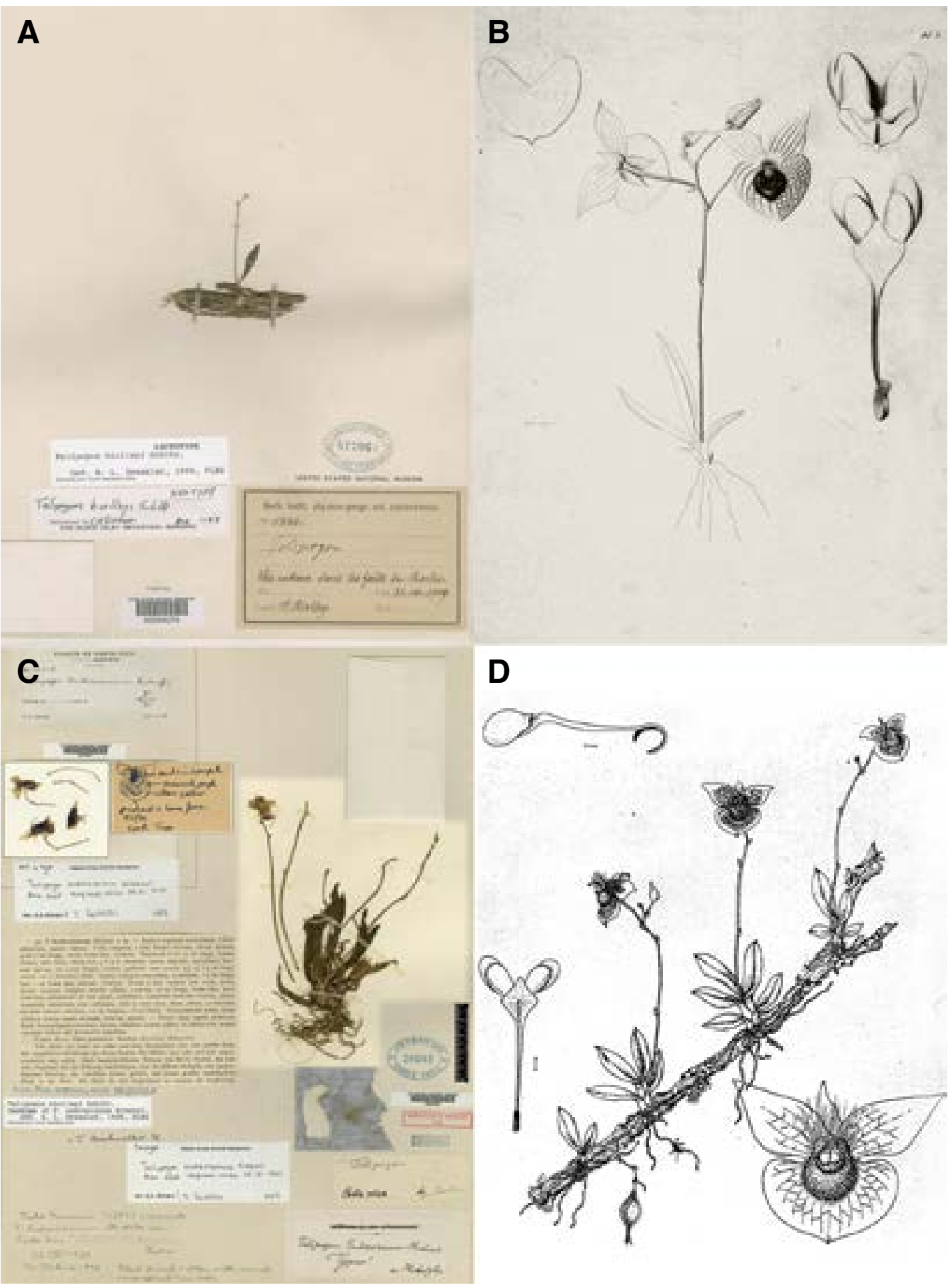

FIgURE 2. A - Lectotype of Telipogon biolleyi (US). B - Drawing of T. biolleyi by A. R. Endrés (W-R). C - Isotype of T. endresianum (AMES). D - Telipogon endresianum, from the Orchid Journal, 1953. 


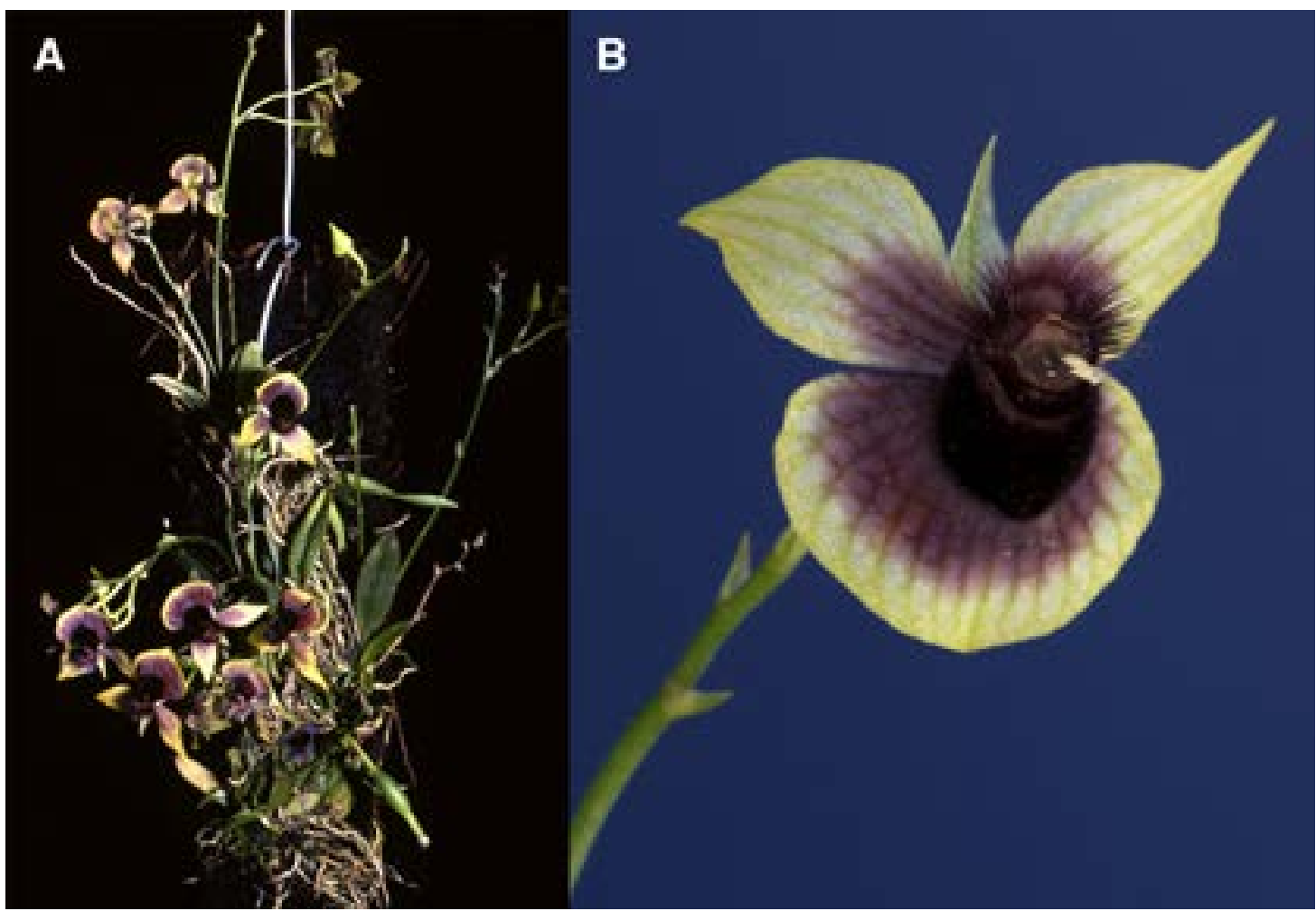

FigURE 3. Telipogon biolleyi. A - habit. B - flower. Photographs by D. Bogarín.

Telipogon endresianum was described by Friedrich Wilhelm Ludwig Kränzlin in 1919 in "Annalen des Naturhistorischen Hofmuseums Wien", Kränzlin dedicated the species to August R. Endrés, his description was based on a perfect drawing and material collected by Endrés (Kränzlin 1919) (Fig. 2B). The type and the drawing are in the herbarium of Reichenbach in Vienna. Kränzlin also mentioned a specimen collected by Huebsch, this specimen is also in Vienna. Another Endrés' specimen, determined as an isotype of Telipogon endresianum is in the AMES herbarium at Harvard (Fig. 2c). A detailed drawing of Kränzlin's species was published by Paul H. Allen 1952 in Alex D. Hawkes' "Orchid Journal" (Allen 1952) (Fig. 2D). It was Dodson who first stated that Telipogon endresianum would be a synonym of the older Telipogon biolleyi.

Telipogon biolleyi (Fig. $3 \mathrm{~A}-3 \mathrm{~B}$ ) is one of the most common species of the genus in Central-America. Like most other species it is a fast growing twig-epiphyte. Most species of Telipogon are very difficult to keep alive in cultivation for more than 2 or 3 years, this problem is known from many small twig-epiphytes. These plants are producing seeds in their second or third year, the generation-succession is fast and due to the fact that their typical habitat is changing fast, they do not survive long in nature. The only way to keep them for a longer time in culture is artificial pollination and propagation from seed. In nature, species of Telipogon are apparently pollinated by pseudocopulation of male Tachinid-flies. The males are attracted by the hairs and bristles around the column of the flowers, perhaps imitating a female fly.

\section{Alberto Manuel Brenes and Campylocentrum brenesii}

When Rudolf Schlechter published 1923 his "Beiträge zur Orchideenkunde von Zentralamerika" in "Feddes Repertorium Beihefte", more than half of the new species he described have been collected by Alberto Manuel Brenes in Costa Rica. Schlechter (1923) dedicated a series of orchid species to Brenes: Barbosella brenesii, Campylocentrum brenesii, 
Catasetum brenesii, Dichaea brenesii, Elleanthus brenesii, Encyclia brenesii, Epidendrum brenesii, Habenaria brenesii, Lepanthes brenesii, Maxillaria brenesii, Microstylis brenesii, Notylia brenesii, Oncidium brenesii, Pleurothallis brenesii, Ponthieva brenesii, Spiranthes brenesii, Stelis brenesii, and Trichocentrum brenesii.

At least in part Alberto Manuel Brenes (Fig. $4 \mathrm{~A}-3 \mathrm{~B})$ also belongs to the Swiss connection like J.F. Adolphe Tonduz and Henry François Pittier. Brenes was born in San Ramon in Costa Rica on September 2th, 1870. He studied in Costa Rica until 1890, when he left Central America for Europe. He stayed in Paris for a short time and then went to Lausanne in Switzerland where he studied at the university for one year, followed by a time in Geneva where he stayed until 1898, taking botany and natural history courses with Professors Renvier, Dufour, Chodat and Briquet.

During the time when Brenes was in Europe, Henry François Pittier founded the Instituto FisicoGeografico Costarricense, a government department devoted to the natural sciences, a part of this institute was the Herbario Nacional de Costa Rica and grew under the strong influence of Pittier. When Pittier left Costa Rica in 1903, the herbarium was taken over by the Museo Nacional. Brenes returned to Costa Rica in 1898 and started teaching at the Escuela de Farmacia (School of Pharmacy) in San Jose. In his spare time he collected plants together with Henry François Pittier, Pablo Biolley and J.F.Adolphe Tonduz. For health reasons Brenes left this appointment in 1903 and returned to San Ramon. In this time he worked for a few years at the Colegio de San Luis Gonzaga and changed to the Escuela Normal in 1911. In 1920 he became the head of the section of botany at the Museo Nacional, a position he held until 1935. In 1921 Brenes began a series of collections that would eventually total more than 23'000 numbers of plant specimens. He usually collected in the very rich forests around San Ramon. The vegetation in this area is extremely rich not only in orchid species but also in other plants because it forms a gap between the Cordillera Central and the Cordillera de Tilaran. Moisture-laden winds from the Caribbean plain are forced up to the eastern slope and across this gap, creating areas of cloud forest at unusually low elevations. Before 1924 the primary set of Brenes collections was deposited in Costa Rica, although the unicates of many groups were sent to specialists. Rudolf Schlechter in Berlin received most of Brenes' orchid collections during this period. After Schlechter's time most of the orchids have been sent to Oakes Ames at Harvard and to the Field Museum in Chicago. Brenes also made a number of pencildrawings of the plants he collected, these drawings are kept at the Departemento de Proteccion del Patrimonio Historico, Museo Nacional de Cost Rica. We don't know how many drawings Brenes made, the drawing of Gongora armeniaca is carrying the number 115 (Fig. 6D) the one of Catasetum macrocarpum the number 272. Seven of them have been printed in the biography of Brenes by Alberto H. Salazar Rodríguez in 2009.

Rudolf Schlechter received trough Tonduz several collections of orchids from Costa Rica, including some specimens collected originally by Brenes. It was Tonduz who told Schlechter to get in direct contact with Brenes. Schlechter wrote 1919 to Brenes, asking him about the possibility to collect orchids for the planned orchid flora of Costa Rica. 1922 Schlechter received a very large collection of specimens from Brenes, the collection was extremely rich in small species from the subtribe Pleurothallidinae and Schlechter decided to publish 1923 the results in an own treatment under the title "Orchidaceae Brenesianae". All species named after Brenes and also the genus Brenesia have been published in this article in "Feddes Repertorium Beihefte". Schlechter's herbarium in Berlin was destroyed during the war in 1943 and all the specimens collected by Brenes were lost. Fortunately Oakes Ames was interested in Schlechter's Central American Orchidaceae and so he paid first an artist and later on Schlechter's wife Alexandra to make drawings of this material for his own herbarium So at least a larger part of Schlechter's collection from Costa Rica survived in form of drawings.

Brenes died in San Ramon in 18. May 1948. Still his name is present in Costa Rica, the journal "Brenesia", published by the Departemento de Historia Natural, Museo Nacional de Costa Rica is named after him, the first number was published in 1972. In the seventies a stamp with Brenesia costaricensis was issued by Costa Rica, in the same series with some other Orchids also a 

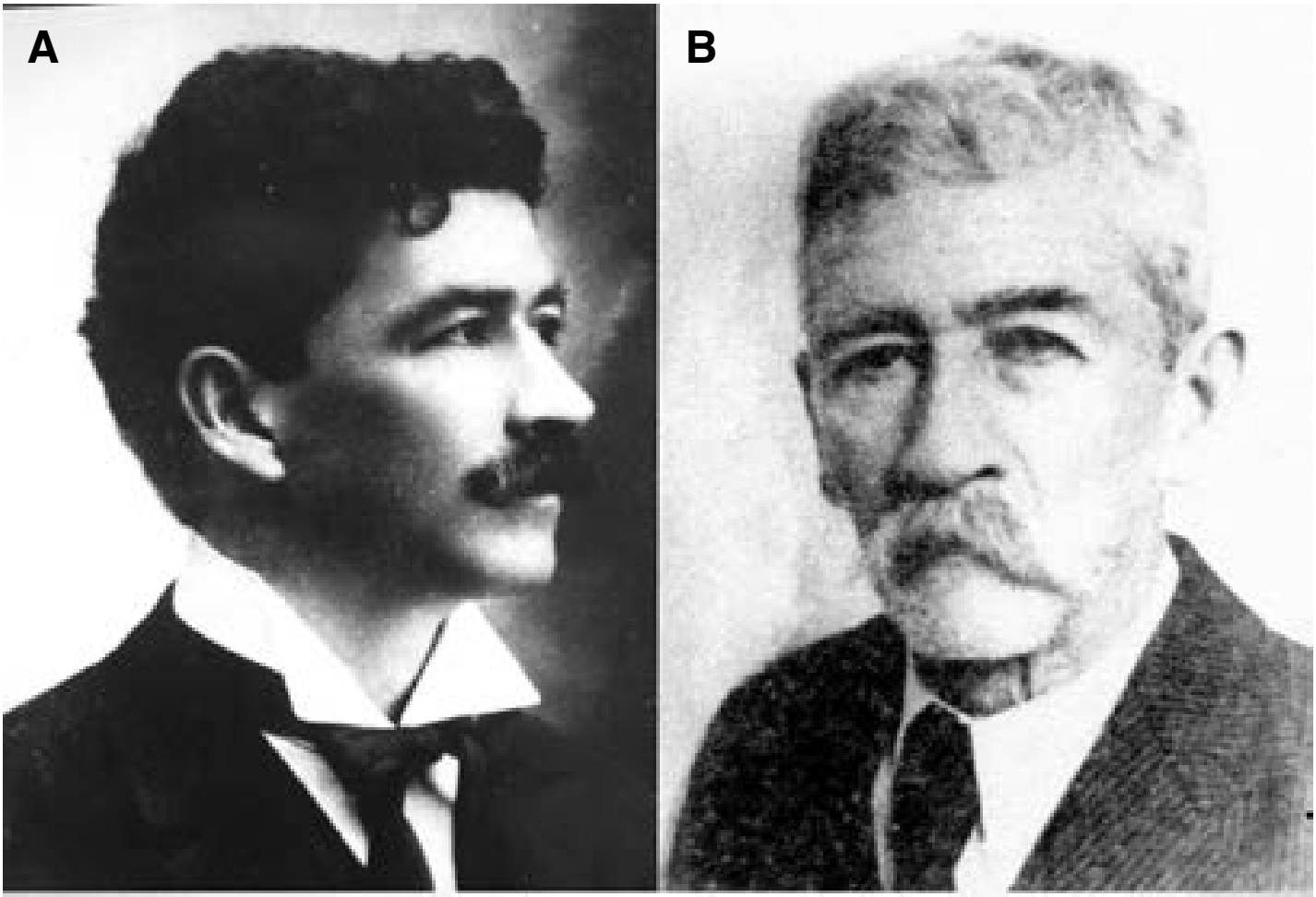

\section{C}
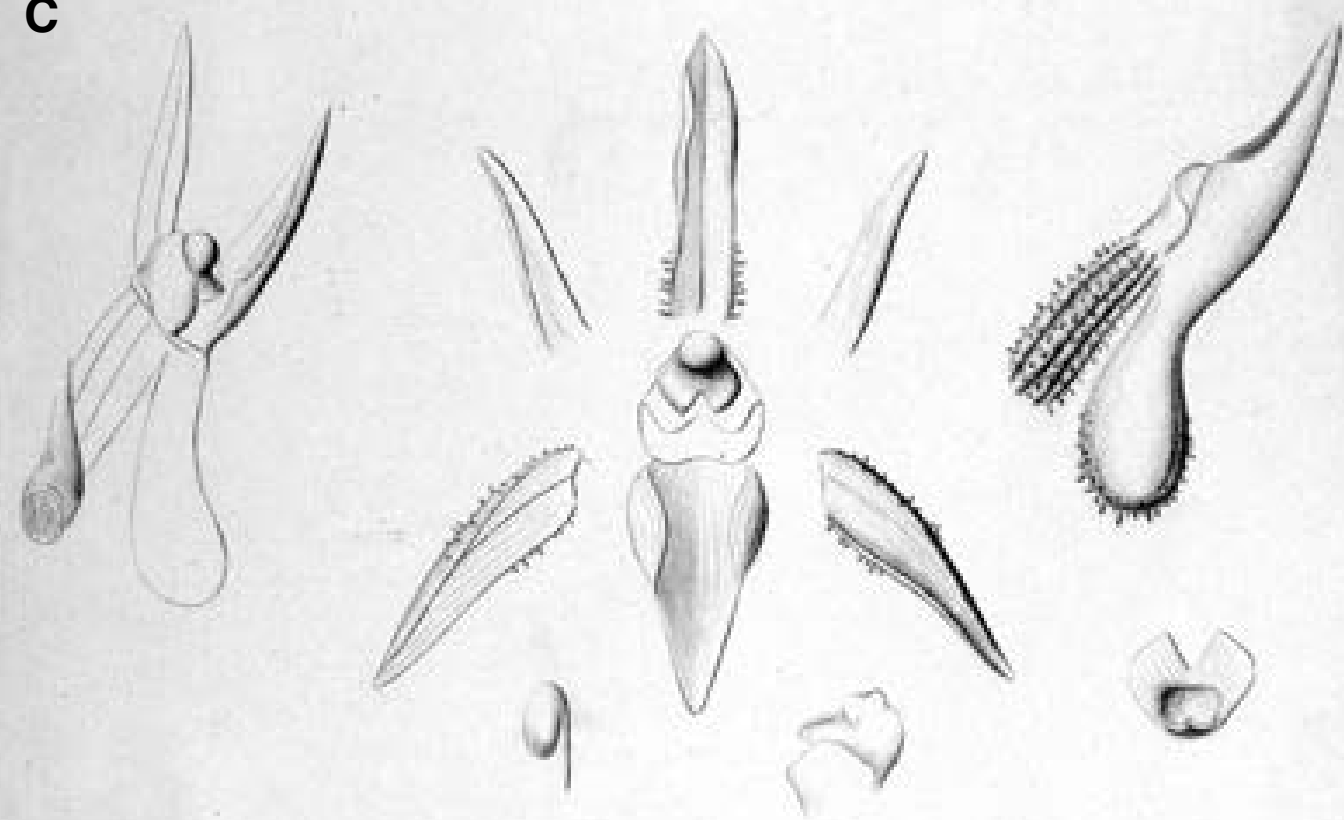

Figure 4. A, B - Two portraits of Alberto Manuel Brenes. C - Drawing of Campylocentrum brenesii by A. R. Endrés

(W-R), from Bogarín \& Pupulin 2010. 

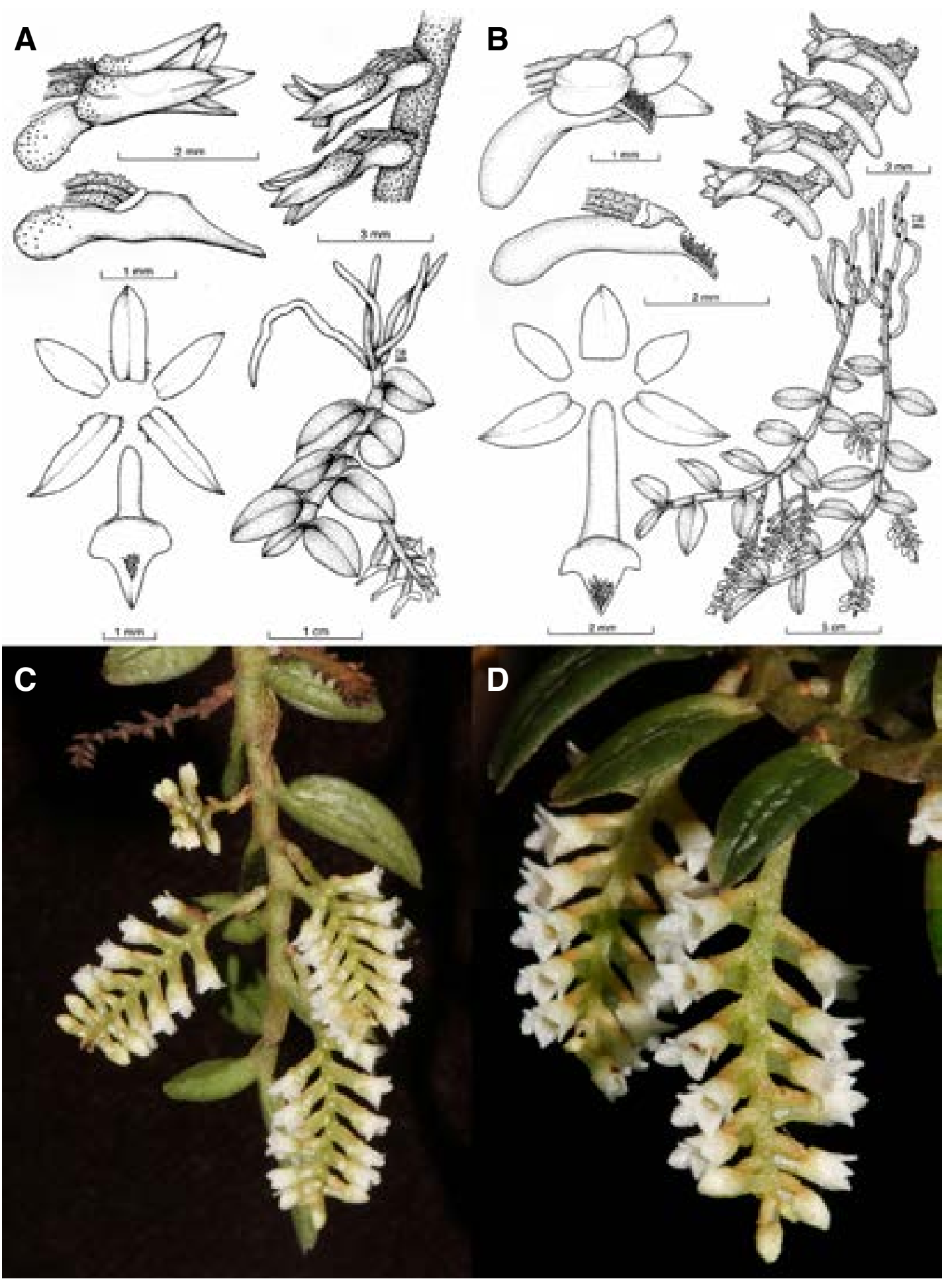

FiguRE 5. A, B - Two modern illustrations of Campylocentrum brenesii by D. Bogarín (from Bogarín \& Pupulin 2010). C, D - Inflorescences of Campylocentrum brenesii. 


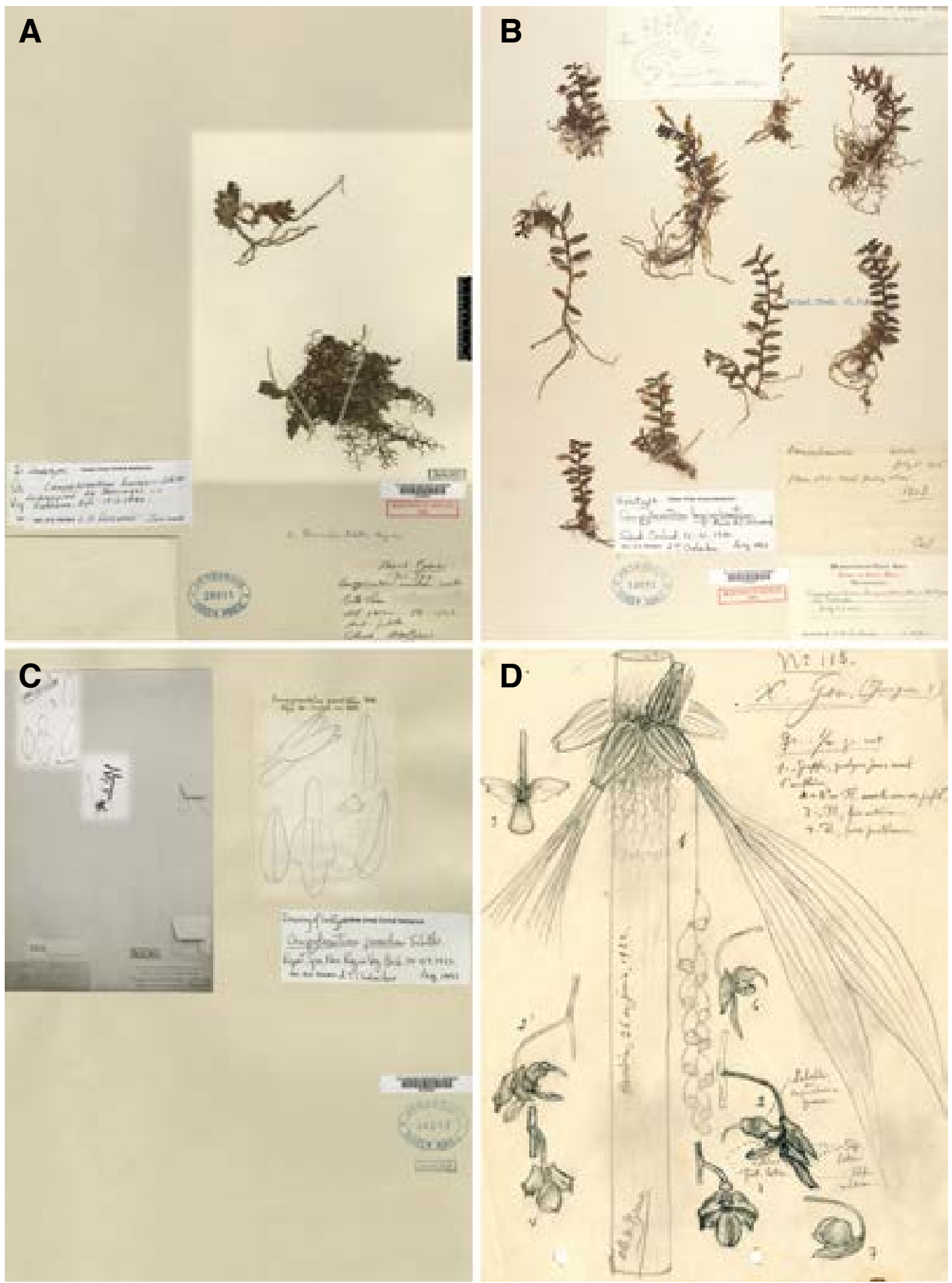

FiguRE 6. A - Lectotype of Campylocentrum brenesii (AMES). B - Holotype of Campylocentrum calcaratum (AMES). $\mathrm{C}$ - Drawing and photograph of the type of Campylocentrum calcaratum (AMES). D - Drawing of Gongora armeniaca by A. M. Brenes (Museo Nacional de Costa Rica). 
stamp with a portrait of Brenes was included.

The genus Campylocentrum was mentioned the first time by George Bentham in 1881 in "Journal of the Linnean Society". The genus belongs in fact to the Angraecinae and includes about 60 species distributed from Mexico to Brazil and Bolivia and in the West Indies. Campylocentrum is a sister genus of Dendrophylax and includes both leafy and leafless species. The genus Todaroa, described in 1844 in "Comptes Rendus Hebdomadaires des Seances de l'Academie des Sciences" by Achille Richard and Henri Galeotti ${ }^{1}$, is today considered as synonym of Campylocentrum. Richard and Galeotti were not aware that the generic name Todaroa was already used for a genus of the Umbelliferae by Parlatore in 1844 . Although Bentham agreed with the concept of Todaroa he could not use this name and proposed instead Campylocentrum as generic name (Bentham 1881). Campylocentrum brenesii was described by Rudolf Schlechter in 1923 in "Beiträge zur Orchideenkunde von Zentralamerika" in "Feddes Repertorium Beihefte" (Schlechter 1923). The plant Schlechter used as type was collected in 1921 by Brenes at San Pedro de San Ramon, Alajuela, Costa Rica. Schlechter's herbarium in Berlin was destroyed in 1943 and the type-specimen of Campylocentrum brenesii was lost (Fig. 6c). Another specimen of the species, also collected by Brenes in September 1921 in Costa Rica was selected by Barringer in 1984 in "Fieldiana Botany" as the lectotype (Barringer 1984) (Fig. 6A). Another specimen of the species was collected by A.R. Endrés in the second half of the $19^{\text {th }}$ century. The specimen remained undescribed in the herbarium of Heinrich Gustav Reichenbach in Vienna, together with two very accurate pencil-drawings by Endrés (Fig. 4c). Brenes collected the species again between 1925 and 1927 in the area of La Palma de San Ramón and at La Paz de San Ramón. Following the most recent revision of the genus Campylocentrum in Costa Rica, published by Diego Bogarín and Franco Pupulin in "Harvard Papers in Botany" from 2010, Campylocentrum longicalcaratum Ames \& Ch.Schweinfurth (Fig. 6b) is a synonym of Campylocentrum brenesii (Fig. 5A-
5D). The plant was collected in July 1925 by Charles H. Lankester near La Estrella, Costa Rica, and was described by Oakes Ames and Charles Schweinfurth in 1930 in "Schedulae Orchidianae". Also Campylocentrum parvulum is defined as synonym of Campylocentrum brenesii., the species was described by Schlechter 1923 in "Feddes Repertorium Beihefte" after a collection by the brothers Alexander Curt Brade and Alfred Brade near La Palma, Costa Rica, in 1400 $m$ altitude.

\section{Richard (Ricardo) Pfau and Trichocentrum pfavii}

We have only little information and details about the life of Richard (Ricardo) Pfau. The family Pfau (Fig. 7A) was very famous in Winterthur near Zurich in Switzerland, 5 generations of Pfau's lived there, they where stove setters and stoves from their business where distributed all over Switzerland and southern Germany. Some members of the family where also active in politics and became members of the town council. Ricardo's father Matthäus Pfau (13.1.1820-27.7.1877) was merchant, officer, banker and politician in Winterthur, and was in 1862 one of the 13 founding members of the precursor of the bank which should become 150 years later the largest bank in Switzerland. In 1865 Matthäus had to retire for health reasons. He bought the Kyburg-Castle and used his fortune to open 1866 the first museum in a historical castle in Switzerland. He moved with family and his art-collection to the Kyburg. Ricardo was the youngest of the three sons of Matthäus Pfau, born in 1856 and grown up at least in part in the Kyburg. The elder brothers where Jakob Pfau (born 1846) who became architect and later Professor at the Technikum in Winterthur, and Eduard (born 1851) who became merchant in Milan, Italy. Ricardo seems to have been the "black sheep of the family". In 1887 he tried to publish a novel and asked Gottfried Keller, famous author in Zurich, for an expertise. However, the result was not as good as expected, the novel was never published. When Robert Keller, botanist and high school teacher in Winterthur, published in

${ }^{1}$ Index Kewensis is defining Richard and Galeotti's publication in "Annales des Sciences Naturelles (ser.3,3:28.1845)" as the valid first description of Todaroa, but the publication in "Comptes Rendus Hebdomadaires des Seances de 1'Academie desSciences" is one year older. If the first description of the genus Clynhymenia in the same publication of 1844 is accepted as valid, the same must be true for Todaroa. 

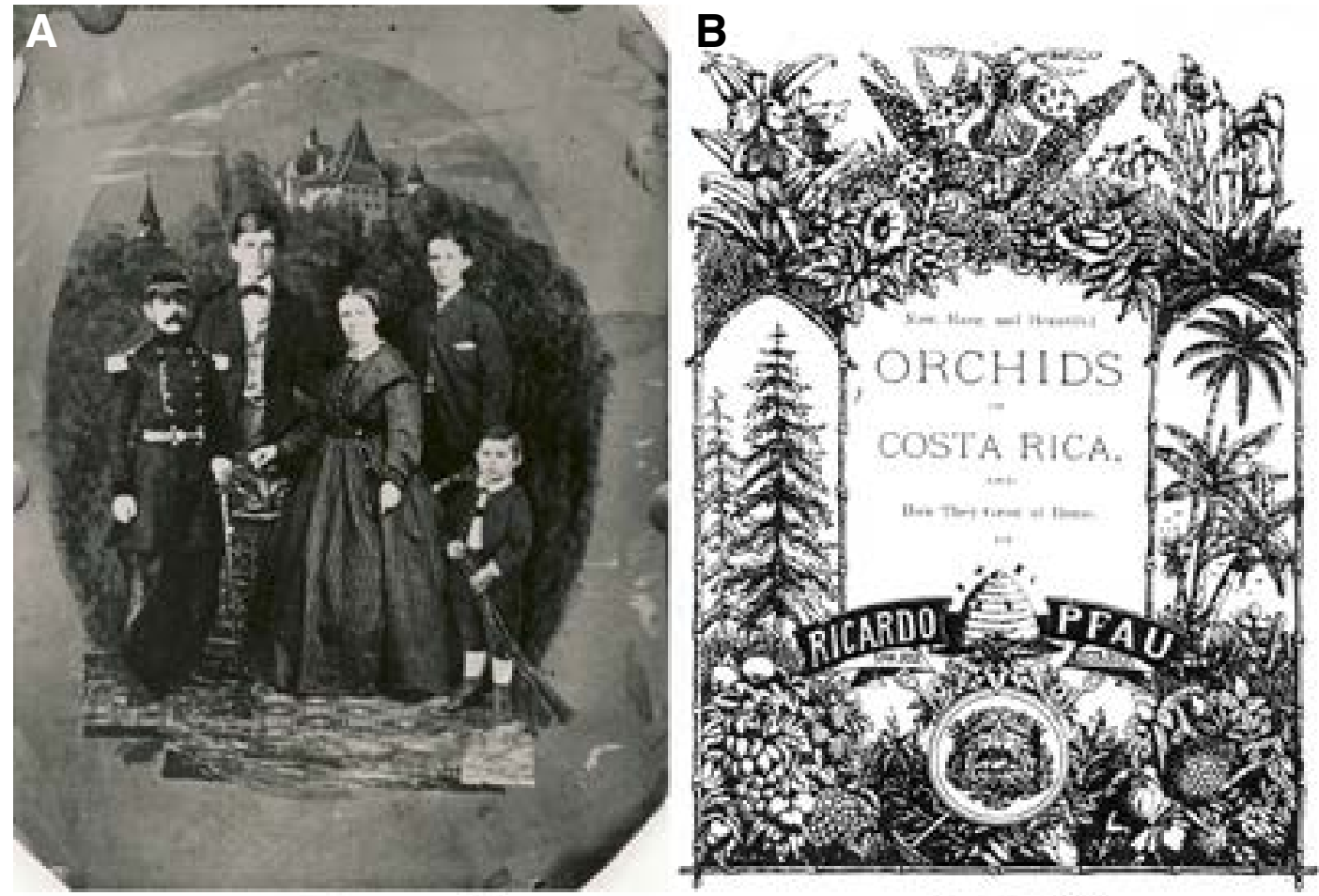

\section{${ }^{c}$ Richard Pfau,} Bee-Keeper. $\rightarrow$

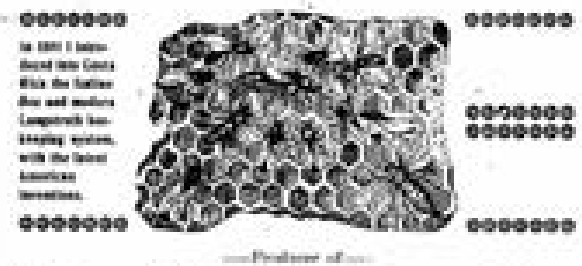

Comb and Extracted Honey, and Wax.

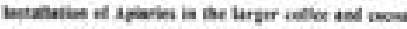

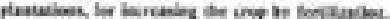

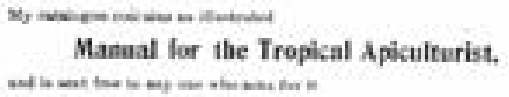

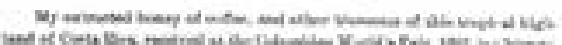

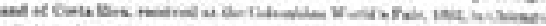

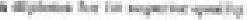

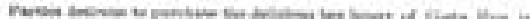

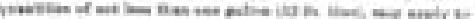

The A. L Root Ca, Mesina, Ohio, U. S, A.

D
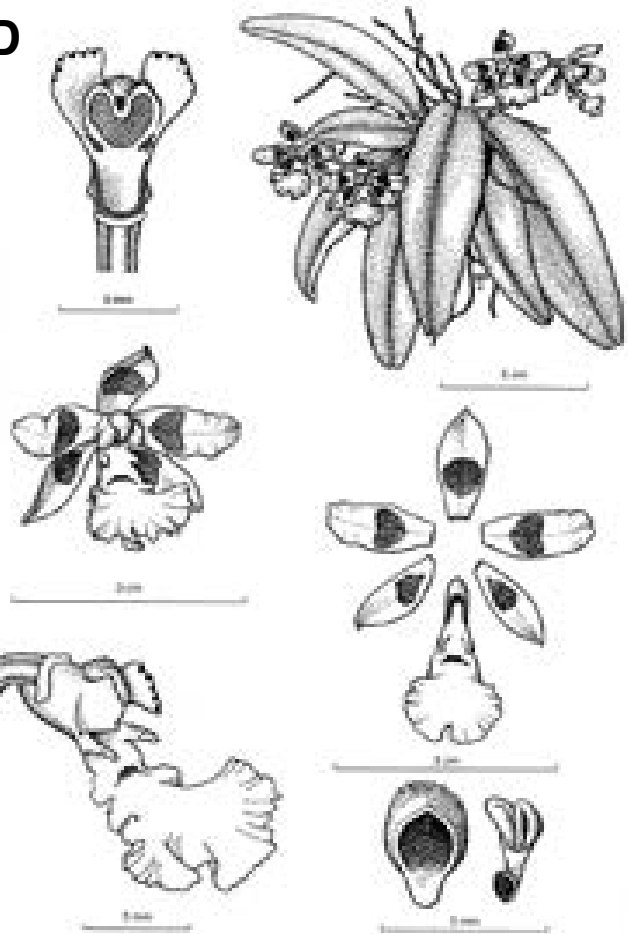

Figure 7. A - The family Pfau; Richard is the boy with a gunon the right. B - Catalogue of Pfau's nursery in Costa

Rica, $c a$. 1895. C - Pfau's illustrated manual for the tropical apiculturist (1895). D - Modern illustration of Trichocentrum pfavii, from Pupulin 1997. 
1891 his "Flora von Winterthur" he mentioned in the introduction also a small collection of plants given to him by his friend Richard Pfau. Obviously Richard had collected plants around the Kyburg.

We don't know when Richard left Europe for Costa Rica the first time but it seems to be around the year 1880. Following some of the articles he published in 1883 and 1884 in "Gardeners' Chronicle" he already had been in Costa Rica but not permanently, he also cultivated Orchids and lived in Chiswick, England. Remarks in the publications like: "...but on experience in my own culture of Orchids in Chiswick, which I began only a few months ago" (Pfau 1883a), “....I discovered this species last year in a locality difficult to get at" (Pfau 1883b) and "....in my houses at Chiswick they seemed to do best in baskets" (Pfau 1883c). In Kew there is a businesscard from Pfau, written in 1895 or 1896 with the following note: "Richard Pfau who thanks to the presentation of the Consul General of Switzerland has had the honor of paying Sir Joseph Hooker a visit 2 years ago before starting for Central-America, begs the favour an interview to show him some new plants he has found". Obviously Richard made several trips to Costa Rica when he lived in England and sometime around 1885 he settled in San Jose, Costa Rica. He returned for a visit in 1893 and again 1896. In "Gardeners' Chronicle" we find a note that Richard succeeded to bring in 1896 a small number of Epidendrum endresii and Miltonia endresii alive to England. Richard founded a nursery in San Jose in Costa Rica, he published - most probably in 1895 - a catalogue of Orchids he had for sale and export (Fig. $7 \mathrm{~B})$. In the catalogue he also gave advice about the cultivation and exportation of Orchids and he made comments like: "Cattleya skinneri, some ten years ago, was a common orchid all over Central America; but in the last few years it has been exported by shiploads; and today - at least in Costa Rica - it has almost become rare". He sent plants to Europe and sold them like other collectors - e.g. Benedict Roezl and Gustav Wallis - through Eduard Ortgies from the Botanical Garden in Zurich. Richard also had an apiary in his nursery, he wrote: "In 1893 I introduced into Costa Rica the Italian Bee and modern Langstroth bee-keeping system, with the latest American inventions", he sold the honey via a company in
Medina, Ohio, USA and offered on demand "an illustrated manual for the tropical apiculturist" (Fig. 7C). Although Richard was as collector mainly active in Costa Rica it is - based on the plants he sent to Europe - probable that he also collected in Colombia, Panama and even Mexico. Richard Pfau died with 41 years on $14^{\text {th }}$ of March 1897.

A few orchids carry his name as epithet (species name), but interestingly all are written as pfavii and not as pfauii. In the Latin alphabet the letter $U$ is written as V, most probably this was the reason for Rolfe, Reichenbach and Schlechter to write pfavii.

Trichocentrum pfavii (Fig. 7D, 8C) was described by Reichenbach in "Gardeners' Chronicle" in 1881 based on material collected 1880 by Pfau in Chiriqui, Costa Rica. Reichenbach got living material, dried specimens and a sketch, the type specimen in the herbarium of Reichenbach (no. 42179) includes two drawings of the species by Reichenbach himself and a few dried flowers (Fig. 7A).

Trichocentrum pfavii var. zonale (Fig. 8D), described in 1883 by Reichenbach in "Gardeners' Chronicle" is a synonym of Trichocentrum pfavii (Reichenbach 1883). The commentary of Reichenbach is interesting: "Mr. Pfau appears to be an excellent correspondent and collector, but his Trichocentrum is an abdominable plant, quite a crux Orchidologorum. It defies all laws, and is polymorphous in the shape of the flowers and nature of the lip." He had got a fresh inflorescence from Veitch and continued: "A fresh inflorescence just sent by Mr. Harry Veitch proves this once more. An unpublished species with much larger flowers and tomentose teeth at the base of the lip, turns out as belonging to this species, though it looked widely distinct. I would not quote this name, Trichocentrum zonale, were it not engraved on an unpublished lithographic plate belonging to one of my unpublished pamphlets. I can only regard it now as a variety".

Trichocentrum pfavii subsp. dotae (Fig. 9A, 9B, 9D) was described by Franco Pupulin in 2001 in "Selbyana" (Pupulin, 2001). The plant was collected in April 1999 by A. Flores (San José, Dota, Santa María, road to San Joaquín) and flowered at Gaia Botanical Garden in 1999, the type specimen is at the herbarium of the Escuela de Biologia, Universidad de Costa Rica (USJ) (Fig. 9B). In the same publication Pupulin 
A
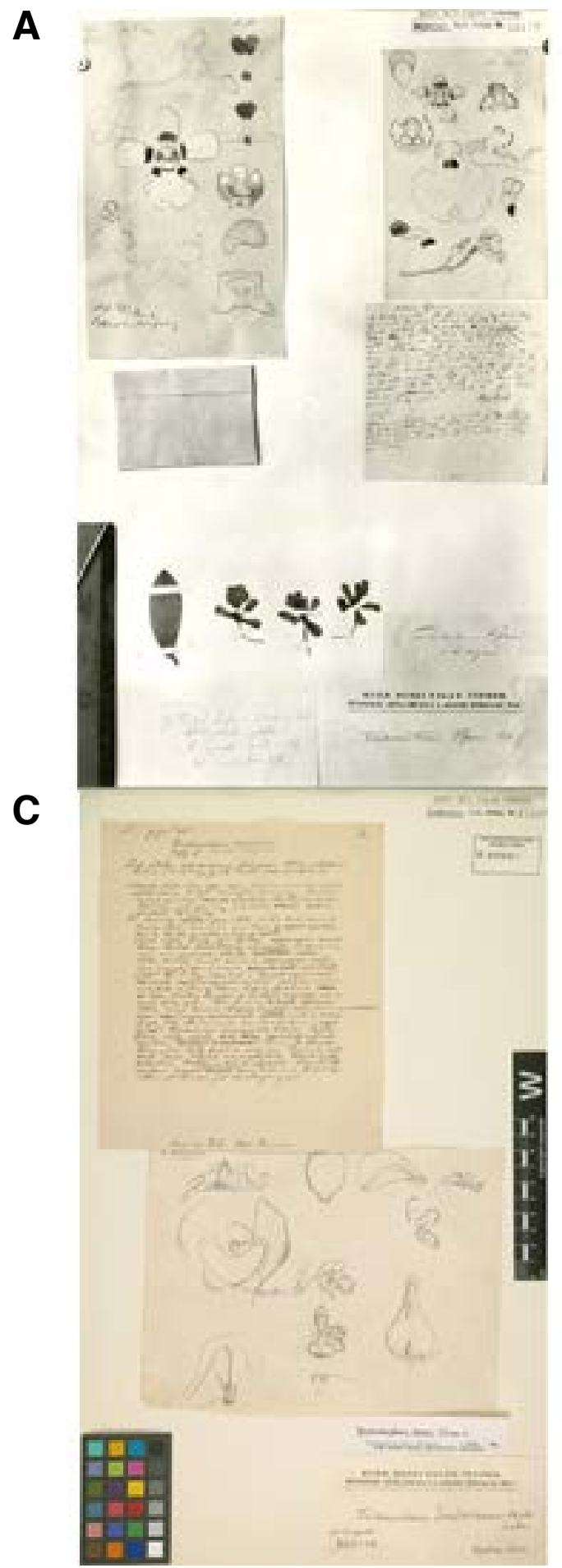

B

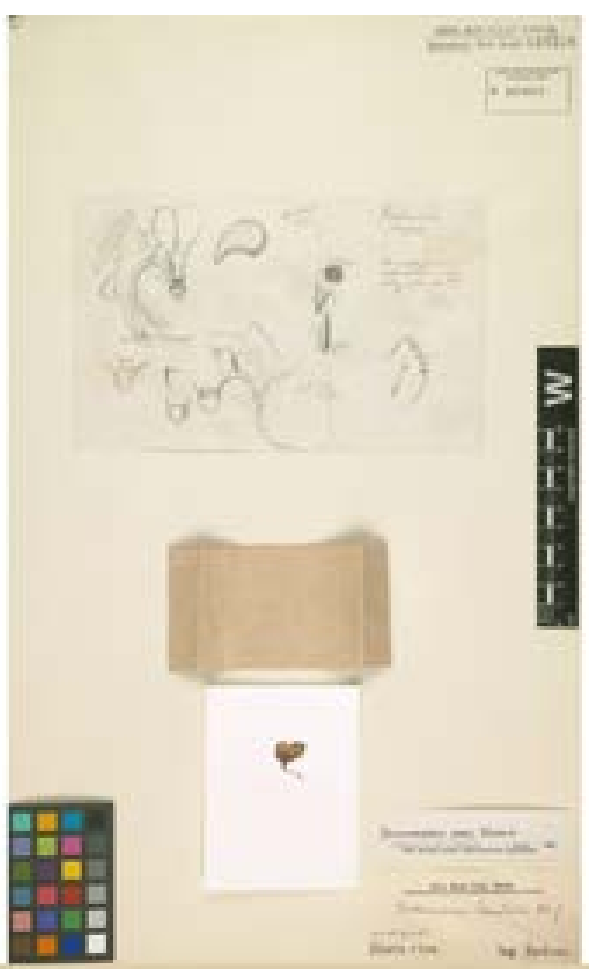

D

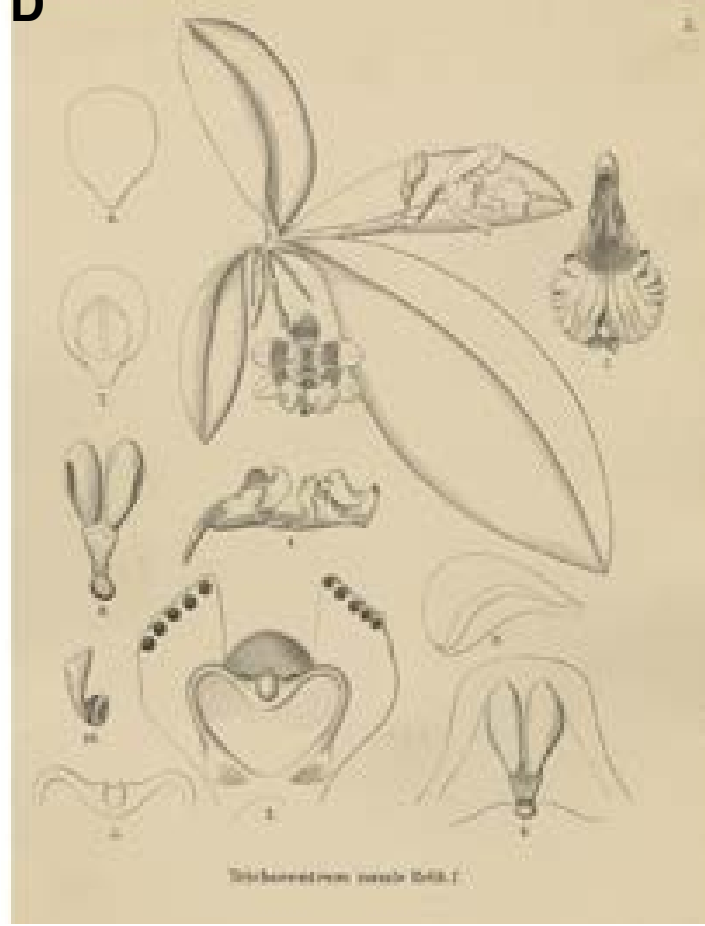

FiguRE 8. A-The holotype of Trichocentrum pfavii at W-R. B, C - Endrés sketches of the species he intended to describe as Trichocentrum saundersii (W-R). D - Unpublished plate of Trichocentrum zonale, from Reichenbach's Xenia Orchidacea. 
A
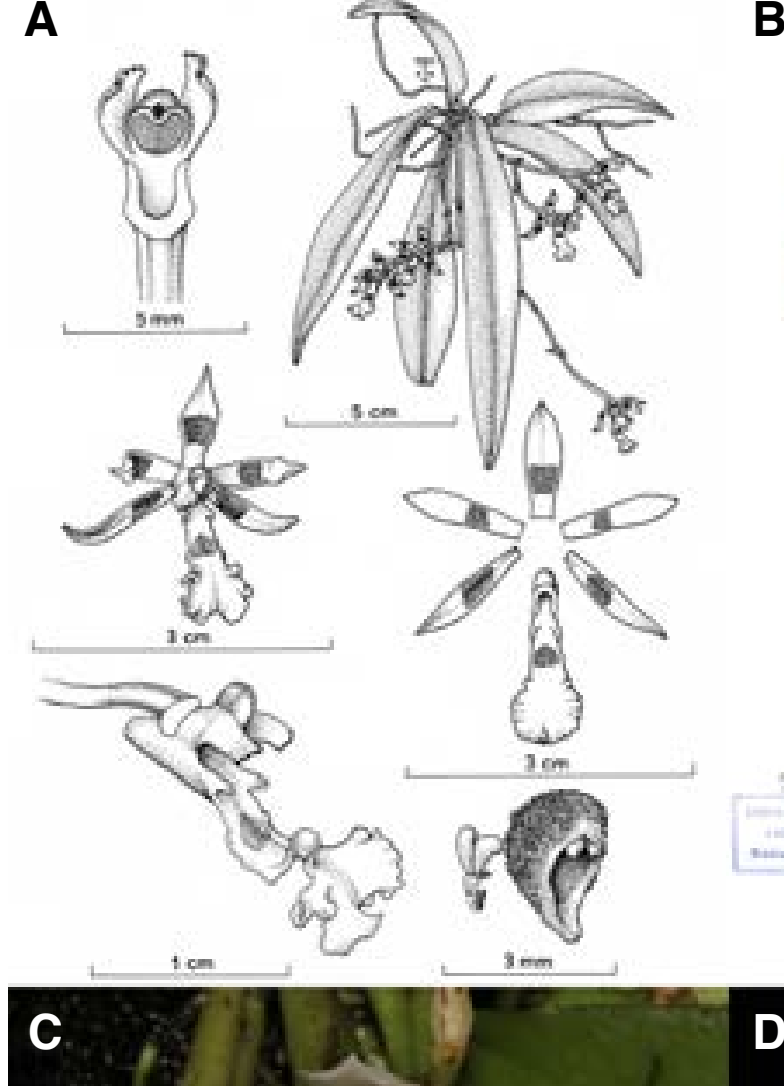

B
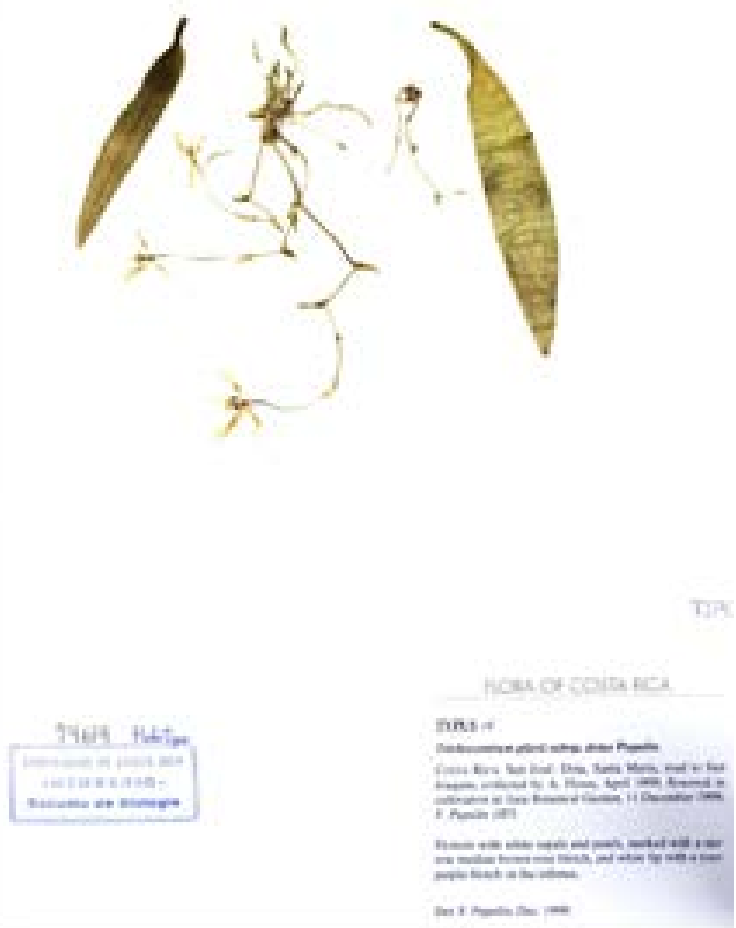

D

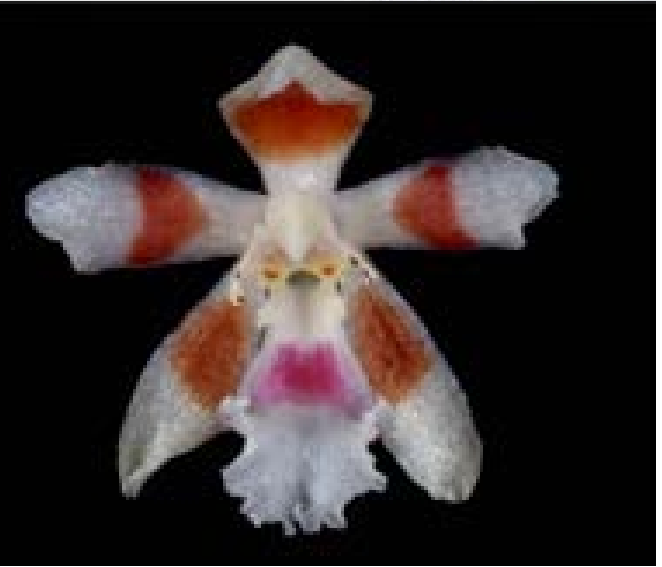

FIGURE 9. A, B - Trichocentrum pfavii subsp. dotae. Original illustration by F. Pupulin (2000), and the holotype in the

Herbarium of the University of Costa Rica (USJ). C — Trichocentrum pfavii. D — Trichocentrum pfavii subsp. dotae (photographs by F. Pupulin).

created a section Lobulatae for the group of species around Trichocentrum pfavii.

Trichocentrum saundersianum and Trichocentrum saundersii are names on several sheets in the Reichenbach herbarium, the material was collected and illustrated by Endrés (Fig. 8B, 8C), but never validly published; it belongs to Trichocentrum pfavii.

\section{Henry François Pittier and Oncidium pittieri}

Henry François Pittier (Fig. 10A-10D) also came from Switzerland. He was born in Bex, Canton Waadt, on $13^{\text {th }}$ of August 1857. He graduated as a civil engineer from the University of Lausanne. After the years at the university he started a map survey of the 
alpine flora of Switzerland. An accident ended with a broken leg and in the following period, immobilized by the accident, Pittier started to read intensively about natural sciences. He got into contact with the work of Haeckel and was so fascinated by Haeckel's ideas that he decided to go to Jena,and a short time later started doctoral studies at the University of Jena in Germany. The information about the academic titles of Pittier are not consistent; following Tobias Lasser, Pittier had a doctorate in philosophy from Jena and from Lausanne a doctorate of science. Following John D. Dwyer, he never finished his studies and remained a bachelor. Following his interests in the tropics, Pittier immigrated in October 1887 to Costa Rica ${ }^{2}$, and never should come back to Switzerland. From 1887 to 1903 he organized and directed the Physico-Geographical Institute of Costa Rica, one of the objectives was to make a map survey of the republic of Costa Rica. It was there that Pittier met Adolphe Tonduz for the first time. Pittier was also involved in the organisation of a National Herbarium in San Jose. Between 1887 and 1904 Pittier collected in Costa Rica, often together with Adolphe Tonduz. One result of those collections was the "Primitiae Florae Costaricensis", which he published in three volumes between 1891 and 1901 in collaboration with Theodore Durand from the Botanical Garden in Brussels.

In 1904 Pittier went to Washington D.C. to work for the United States Department of Agriculture under the very promising title "Special agent in botanical investigation in tropical agriculture in the Bureau of plant industry". The title was changed to Botanist in 1912. Between 1905 and 1919 he worked in Washington in his office and travelled extensively in Central and South America, he collected in Panama,
Mexico, Guatemala, El Salvador, Colombia and in Venezuela. Pittier's collections in Panama have been very important for the Flora of Panama.

At the age of 62 he left Washington and went to Venezuela as director of the Commercial Museum in Caracas. Again and in spite of his age he travelled extensively in Venezuela and published the famous "Manual de las Plantas usuales de Venezuela" in 1926 and its first supplement in 1939. Pittier also founded the National Herbarium in Caracas and published some 300 books and articles in different journals. He died in Venezuela at the age of 93 in $1950 .^{3}$ There are still discussions about the final number of plants collected by Pittier, but without any doubt he made a very important contribution to the knowledge of the floras especially of Panama, Costa Rica and Venezuela. Several orchids are dedicated to this important botanist, mainly by Rudolf Schlechter in Berlin, who got Pittier's orchids for identification. Some of them are Oncidium pittieri Schltr., Maxillaria pittieri Schltr., Scaphosepalum pittieri Schltr., Pleurothallis pittieri Schltr., Lockhartia pittieri Schltr., Vanilla pittieri Schltr., and Epidendrum pittieri Ames

Unfortunately most of Pittier's orchids have been destroyed during the second world war in Berlin, together with almost the entire herbarium of Schlechter. Some of the species have been illustrated in 1931 in "Feddes Repertorium", based on the original drawings of Schlechter and published by Rudolf Mansfeld.

Oncidium pittieri was described by Rudolf Schlechter in 1910 in "Feddes Repertorium" (Schlechter 1910). The plant was collected by Pittier near La Palma in Costa Rica in September 1896. The type specimen was destroyed in 1943 but a copy of it is still in the AMES herbarium (Fig. 10A). The flower

${ }^{2}$ Pittier come to Costa Rica hired by the government. See Ossenbach 2009: "However, the last two decades of the century showed for the first time the development of a 'national science' in Central America. In Costa Rica, "as part of an educational reform aimed at secularizing public education, the government of president Bernardo Soto (1885-1889) hired a group of European academics to staff the two new public high schools in the capital, San José (The 'Liceo de Costa Rica' for boys and the 'Colegio Superior de Señoritas' for girls, both founded under Soto's administration). The arrival of these academics marks the beginning of a small scientific renaissance in Costa Rica. Two institutions symbolize this renaissance: the Instituto Físico-Geográfico (IFG) (= 'Physical-Geographical Institute') and the National Museum, founded in 1887 and 1889, respectively." Among the hired teachers were Pablo Biolley (1861-1908) and Henri Francois Pittier (1857-1950), who arrived in 1886 and 1887.

${ }^{3}$ Henri Pittier National Park is the oldest national park in Venezuela, originally created in 1937 under the name of Rancho Grande by decree of President Eleazar López Contreras. The park was renamed in 1953 with the name of Henri Pittier, who arrived in Venezuela in 1917, classified more than 30,000 plants in the country and devoted many years studying the flora and fauna in the park. 


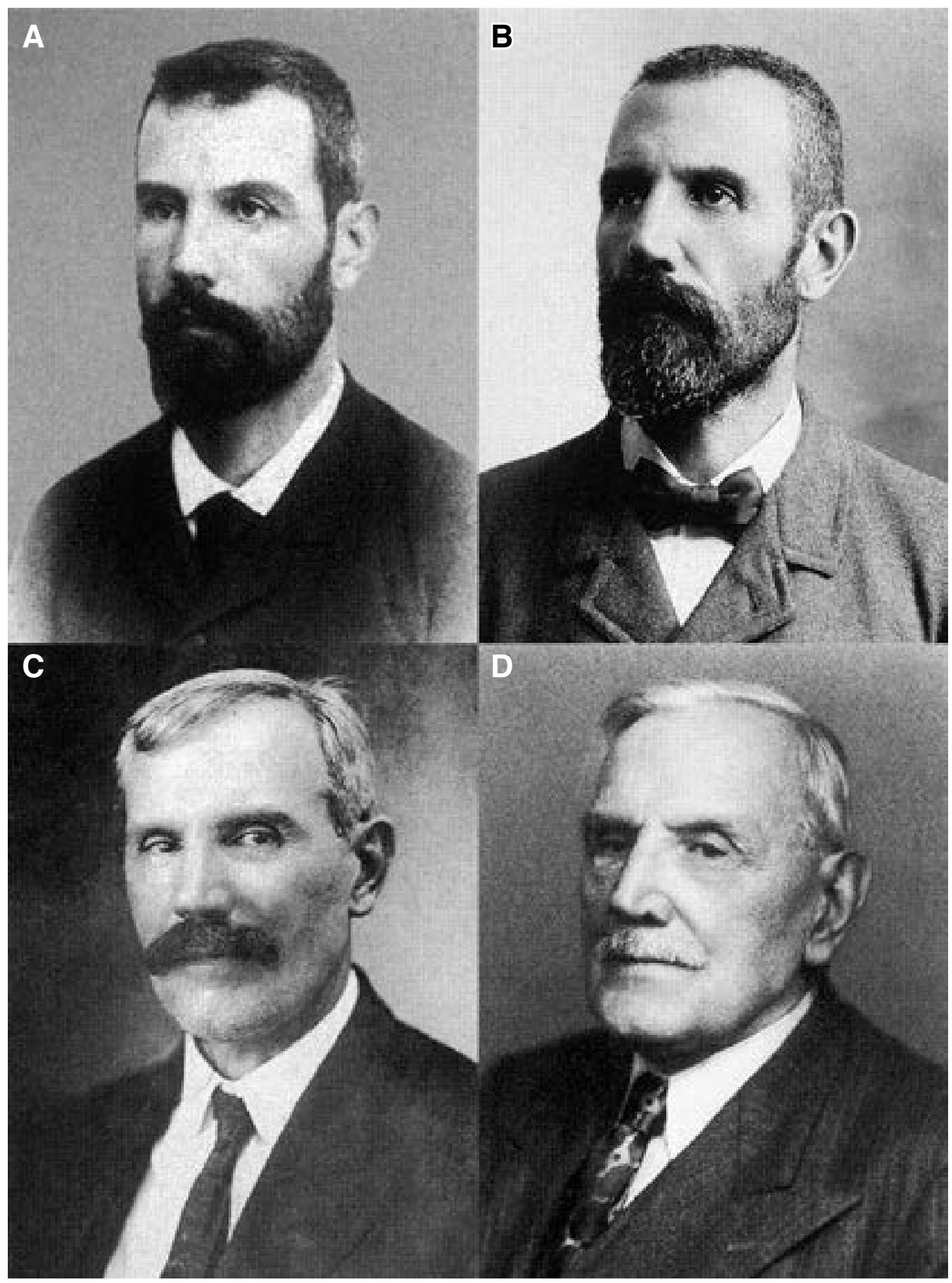

Figure 10. Portraits of Henry Francois Pittier. A — In 1880. B — In 1903. C — In 1914. D — In 1946. 


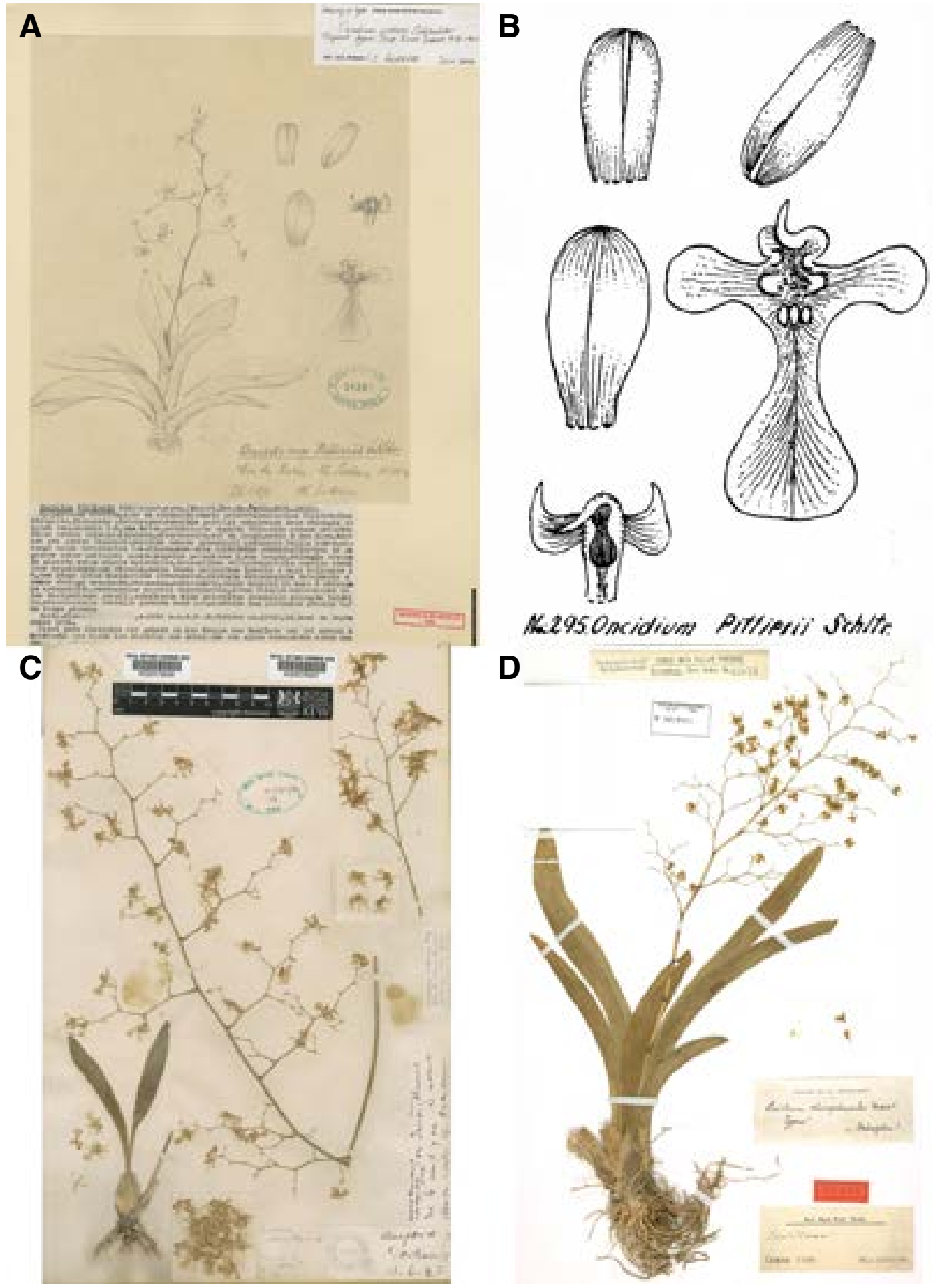

FIGURE 11. A - Oncidium pittieri, copy of Schlechter's drawing of the holotype. B - O. pittieri, Schlechter's sketch of the flower, published by Mansfeld (1931). C — Type of Oncidium luteum (K). D — Type of Oncidium cheirophoroides (W). 


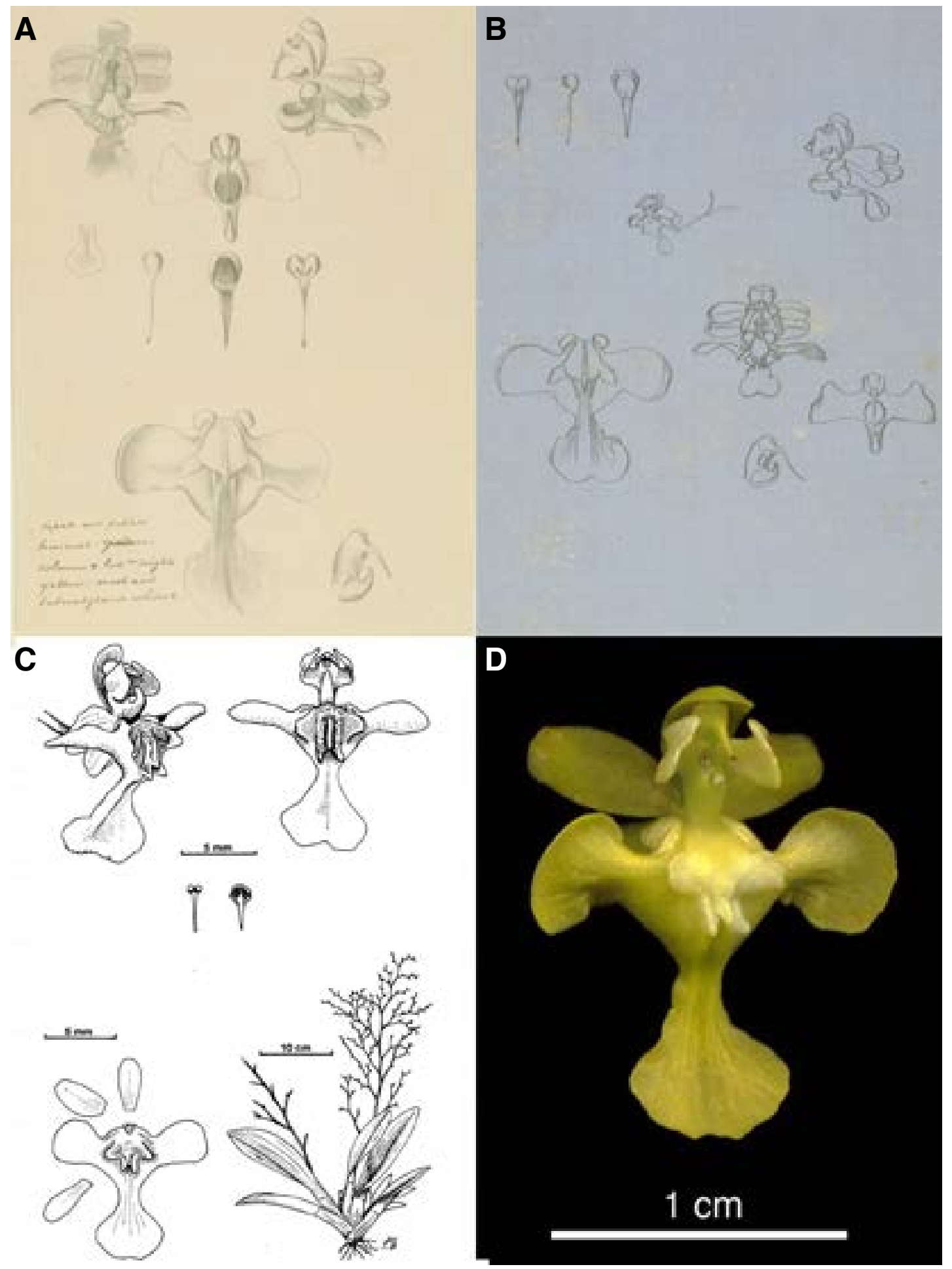

FiguRE 12. Oncidium luteum. A, B - Sketches by A. R. Endrés (W-R). C - Illustration from Icones Plantarum Tropicarum (pl. 1572). D - Photograh of the flower, by D. Bogarín.. 
dissection on this drawing is exactly the same as published by Mansfeld in 1931 (Fig. 11B) in "Feddes Repertorium Beihefte" (Mansfeld 1931). Obviously Schlechter was not aware of the existence of Oncidium luteum, described by Robert Allen Rolfe in 1893 in "Bulletin of Miscellaneous Information"(Rolfe 1893a). Rolfe's description was based on a plant cultivated in the collection of Trevor Lawrence in Burford Lodge and sent in summer 1892 to Kew for determination (Fig. 11c). It is not known from where Lawrence had the plant. Following descriptions, drawings and typematerial, it is clear that - unfortunately - Oncidium pittieri has to be declared as synonym of the older Oncidium luteum (Fig. 12D, 12D).

Oncidium cheirophoroides is another synonym of Oncidium luteum, it was described by Friedrich Kränzlin in "Das Pflanzenreich" in 1922 (Kränzlin 1922). The material Kränzlin used was collected in Costa Rica by Endrés, the type specimen is in the herbarium of Reichenbach in Vienna (no.45055) (Fig. 11D). Two drawings by Endrés of an un-named Oncidium in the Reichenbach herbarium (no.33448 and 33732) (Fig. 12A, 12B) are showing also Oncidium luteum (determinated by Dressler in 2001).

\section{Jean François Adolphe (Adolfo) Tonduz and Masdevallia tonduzii}

Jean François Adolphe Tonduz (Fig. 13A, 13B) was born as the youngest of 7 children of Paul Gustave Tonduz on 18 September 1862 in Pully, Canton of Waadt, Switzerland. Between 1876 and 1881 he studied at the Technical School in Lausanne, after this he started to study medicine at the University of Lausanne from 1881 to 1885 . During this time he got into contact with botany, and influenced by two of his teachers, J.B. Schnetzler and L. Favrat, he got more and more interested in natural history and especially botany. This was the reason why in 1885 he moved as Conservator to the Botanical Museum of the Botanical Institute of the same University in Lausanne. In 1889 William Barbey offered him to become Conservator at the Herbarium Boissier in Geneva, and it was Boissier himself who helped Tonduz in the same year to get an employment from the government of Costa Rica to study coffee-diseases. In May 1889 Tonduz

\footnotetext{
${ }^{5}$ Popular name in Costa Rica for a small grocery store.
}

left Geneva and arrived in Costa Rica on June 17th. A short time after his arrival he got into contact with Henry Francois Pittier de Fabrega, another Swiss active as botanist in Costa Rica. Soon they became good friends and together they travelled between 1889 and 1903 through Costa Rica. In 1889 Tonduz became collector for the Instituto Fisico-Geografica Nacional, founded by Pittier. Both collected some 20 '000 specimens. Most of the herbarium specimens have been distributed by T. Durand, director of the Botanical Garden in Brussels, to different institutes. Almost complete sets are kept at the Conservatoire Jardin Botanique in Geneva and at the Smithsonian Institution in Washington. Between 1903 and 1920 Tonduz was employed at the Costa Rican Museo Nacional. In 1920 he went to Guatemala and worked there as plant pathologist for the Agricultural Service. He died in Guatemala on $20^{\text {th }}$ of December 1921 at the age of 60. In one of his biographies his life is described as very eventful, changing from poorness to times of no financial problems, he himself is described as cultivated, generous and friendly. When Tonduz was not travelling he lived in San Francisco de Guadalupe, ${ }^{4}$ where a road is named after him.

The last orchid collection from Tonduz reached Rudolf Schlechter in Berlin in 1921. After the war Rudolf Schlechter tried to find contact to collectors in Central America in order to finish his orchid flora of Central America. He got positive answers from several people, among them Don José C. Zeledón and his wife Doña Amparo de Zeledón in Costa Rica. Doña Amparo owned a large collection of orchids, mainly from Costa Rica and she allowed Tonduz and also Wercklé to select interesting material from her collection, she herself also paid Wercklé for his work. The genus Amparoa, Habenaria amparoana, Sobralia amparoana and Gongora amparoana are dedicated to her. Most of the species described by Schlechter in his article Orchidaceae Amparoanae in "Feddes Repertorium Beihefte" (Schlechter 1923) had been sent to him by Tonduz and were from plants from Doña Amparo's collection. Together with his own material, Tonduz sent a few plants collected by Alberto M. Brenes and helped Schlechter to get into direct contact with Brenes. During his time in Costa Rica, Tonduz kept the contact to the Botanical Garden 


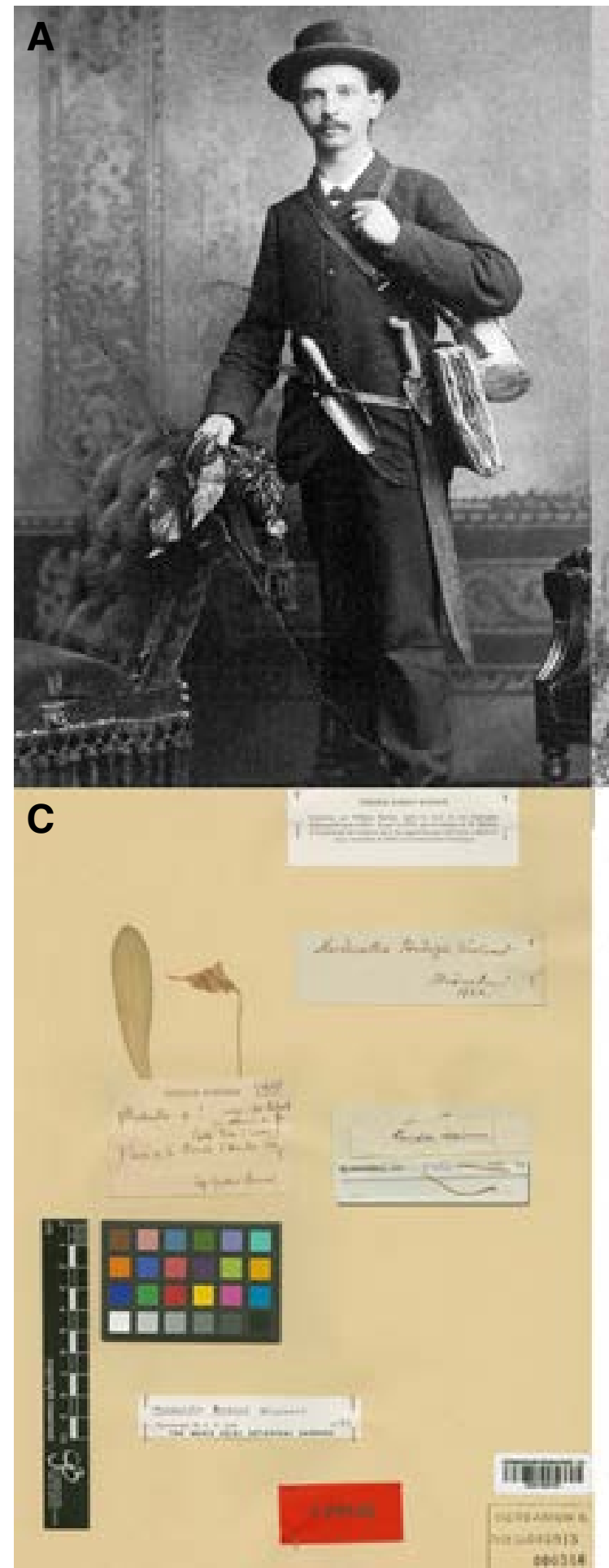

B

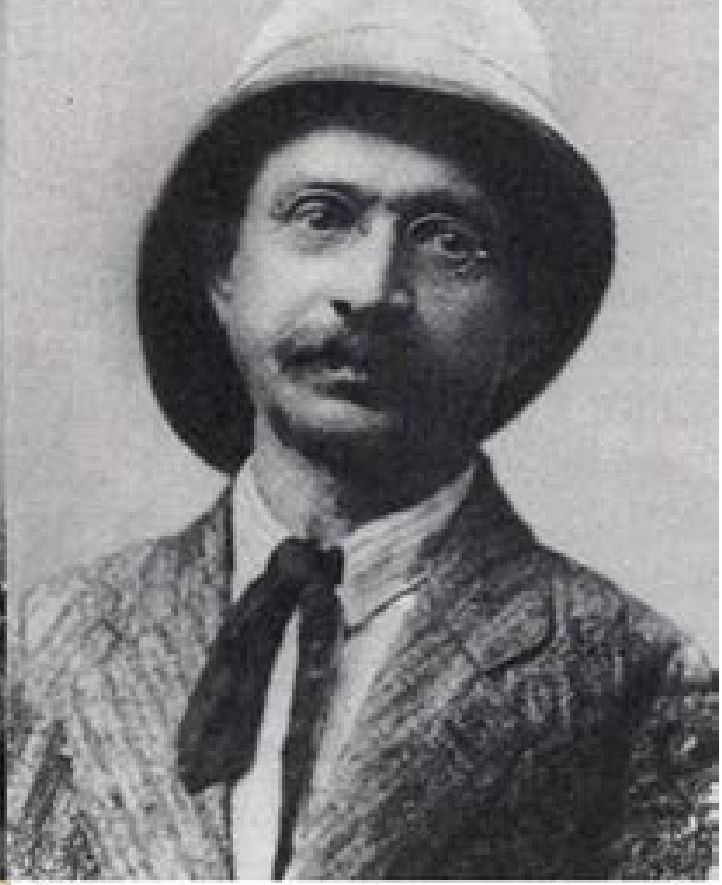

D

\section{MASOEVALLII TONOUZII Spac. tor.}

nas

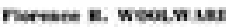

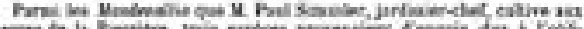

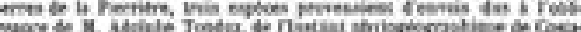

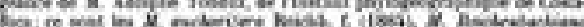

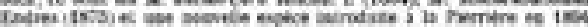

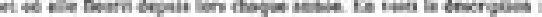

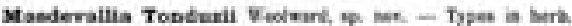
Burter owiver:

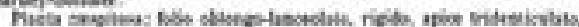

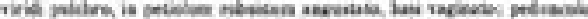

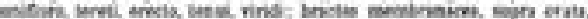

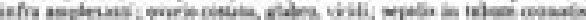

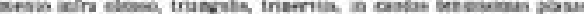

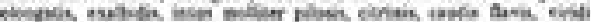

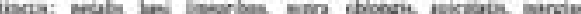

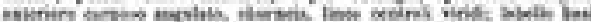

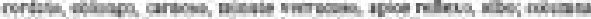

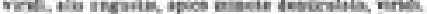

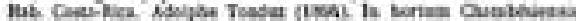

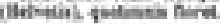

Figure 13. A, B - Portraits of Adolphe Tonduz when in Costa Rica. C - The holotype of Masdevallia tonduzii at G. D - Protologue of Masdevallia tonduzii, from Bulletin de l'Herbier Boissier (1906). 

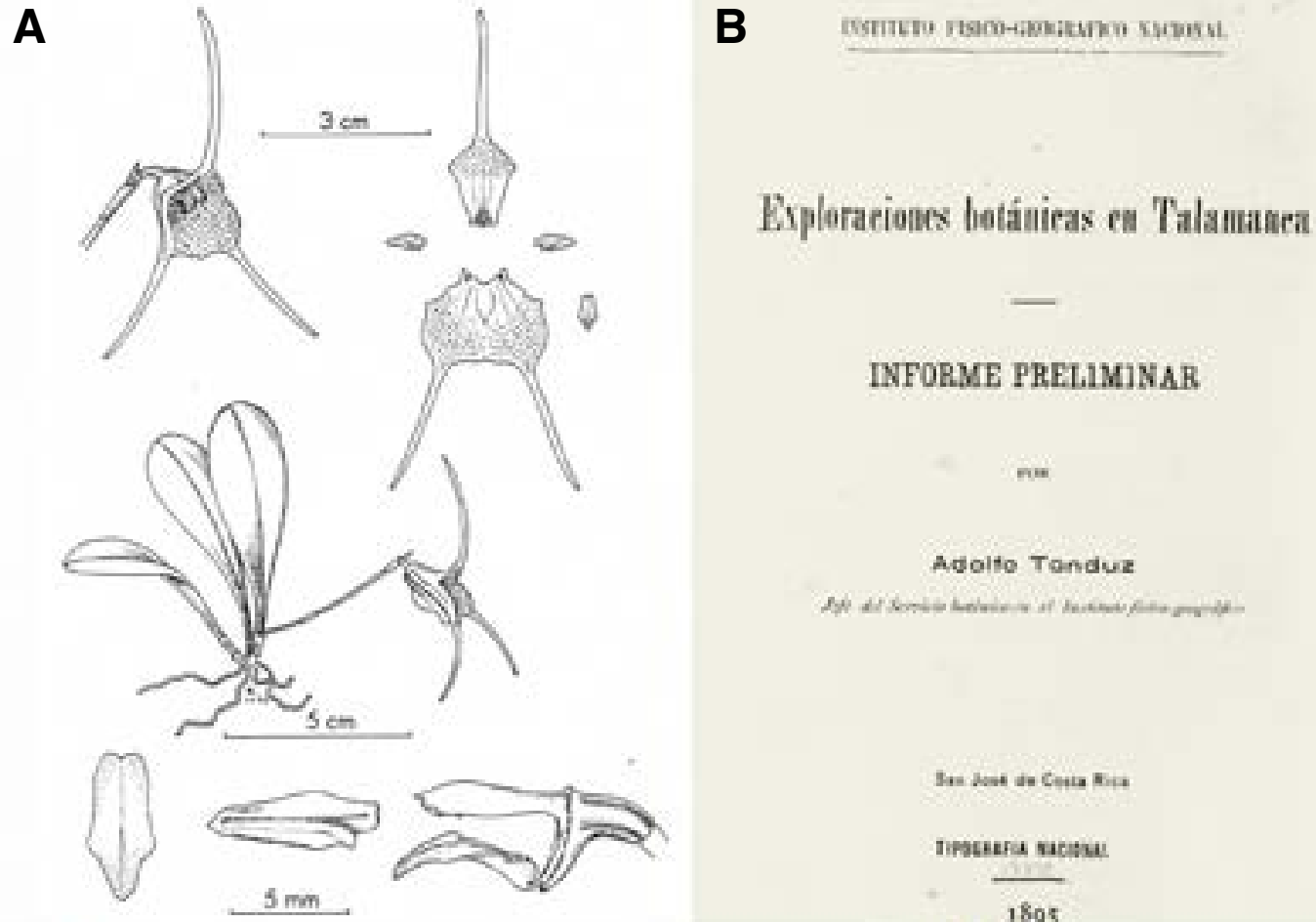

\section{INFORME PRELLIMINAB}

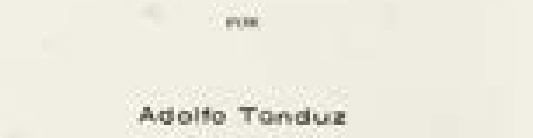

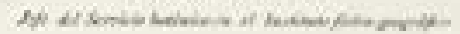

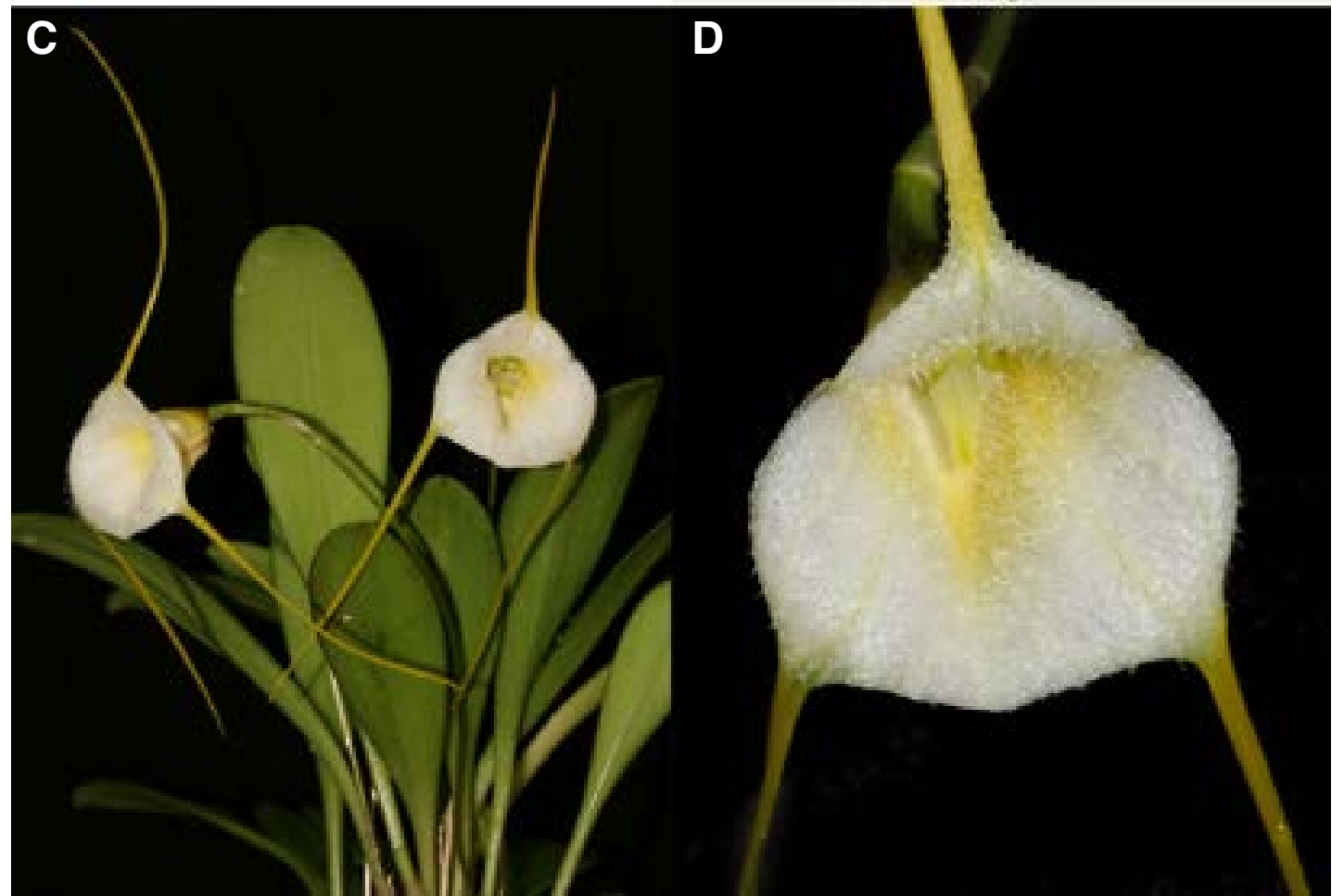

Figure 14. A - Masdevallia tonduzii, illustration from Icones Pleurothallidinarum 22 (2001). B — Frontispiece of Tonduz' "Exploraciones botánicas en Talamanca" (1895). C, D — Masdevallia tonduzii, habit and flower. Photographs by R. Jenny. 
in Geneva and sent from time to time living material to Geneva. There are only a few known publications by Tonduz, one is "Exploraciones botanicas efectuadas en la parte meridional de Costa Rica" in 1893, two others are "Exploraciones botanicas en Talamanca" in 1895 (Fig. 14B) and "Herborisations au Costa Rica" in 1895 - 1897. The latter was published in several parts in the "Bulletin de l'Herbier Boissier", it is a very detailed diary of some of his travels in Costa Rica.

Three genera are dedicated to Tonduz, Tonduzia Pittier (1908, Apocynaceae), Tonduzia F.L.Stevens (1927, invalid) and Tonduzia Boeck. ex Tonduz (Cyperaceae, 1895). Several orchid species are dedicated to Tonduz (Schlechter 1923), unfortunately only a few of them have been illustrated: Elleanthus tonduzii, Stelis tonduziana, Camaridium tonduzii, Restrepia tonduzii, Cycnoches tonduzii, and Masdevallia tonduzii (Woolward 1906).

Masdevallia tonduzii (Fig. 14A, 14C, 14D) was described by Florence Woolward in "Bulletin de l'Herbier Boissier" (Woolward 1906) (Fig. 13D), the plants had been collected by Tonduz and were incorporated in 1894 in the orchid collection of the Conservatoire Jardin Botanique in Geneva. Under cultivation of Paul Simmler Masdevallia tonduzii flowered every year, but only in 1900 Florence Woolward realized that it was a new species when she got some plants in her hands. Unfortunately it was too late to include the species in her famous book The Genus Masdevallia and she did not publish an illustration together with the first description. The plants remained in cultivation in Geneva at least until 1910 , the type specimen is in the herbarium Boissier in Geneva (Fig. 13C).

\section{Karl (Carlos) Wercklé and Kefersteinia wercklei}

Karl (Carl, Carlos) Wercklé (Fig. 15A) was born on $18^{\text {th }}$ of July 1860 in the village Wiebersweiler (Vivverville) in the department Alsace-Lorraine in France as son of Carl Wercklé and Christine Deher. We don't know much about his early years, but obviously he visited the secondary school in Nancy. It is said that Wercklé was a man of extraordinary education, he was fluent in Spanish, German, French and English and it is also said that he understood enough of Latin, Greek and even Hebrew to read books in those languages.
Beside this he had also skills as cartographer and as philosopher. We don't know whether the story about his German manuscript "The Philosophy of the Absolute" which he planned to publish and which was stolen from his home and used in a local pulperia ${ }^{5}$ to wrap soap and candles, is entirely true. Although French by birth Carlos always insisted to be German.

Sometime around 1892 Wercklé - most probably with his oldest sister Julia - left Europe for the USA and worked for the company of John Lewis Childs (Fig. 15B) of Long Island, New York. Childs (18561921) was selling seeds and bulbs and was founder of Floral Park (Fig. 15c). The only photograph of Wercklé we know shows him together with his boss John Lewis Childs and Anastasio Alfaro visiting an exhibition in 1893 in Chicago (Fig. 15A). Wercklé was sent to Costa Rica to collect plants and seeds for Childs, he arrived for the first time in Costa Rica in 1897; following some sources he had his sister Julie with him. He had Theophile Brune, another plant collector, with him or he met him for the first time in Costa Rica. We know that because some of Wercklé's collections of orchids were dated November 1897, and there are specimens of the fern Loxomopsis costaricensis in the herbarium of Hermann Christ, described in 1904 and collected by Wercklé and Brune. Carlos' sister got pneumonia and went back to the USA where she died a short time later. Carlos went with her and was 1898 employed by the Rose Hill Nursery of Henry A. Siebrecht and Albert Wadley of New Rochelle, a company specialized in tropical plants, ferns, palms and orchids. The company published catalogues in regular intervals and set up own orchid shows in New York. Obviously Wercklé also had relations to the New York Botanical Garden, he tried to find help to finance another trip to Costa Rica from the company and from Nathaniel Lord Britton, at this time director of the New York Botanical Garden. He had no success and so he returned on his own resources to Costa Rica, he reached Puerto Limon on $7^{\text {th }}$ July 1902.

Rudolf Schlechter, orchidologist in Berlin, was trying to get contact to collectors in Central America in order to complete his planned orchid flora of Central America. He got positive answers from several people, among them also Don José Castulo Zeledón and Doña Amparo de Zeledón (Fig. 15D). Doña Amparo owned a large collection of orchids, mainly 

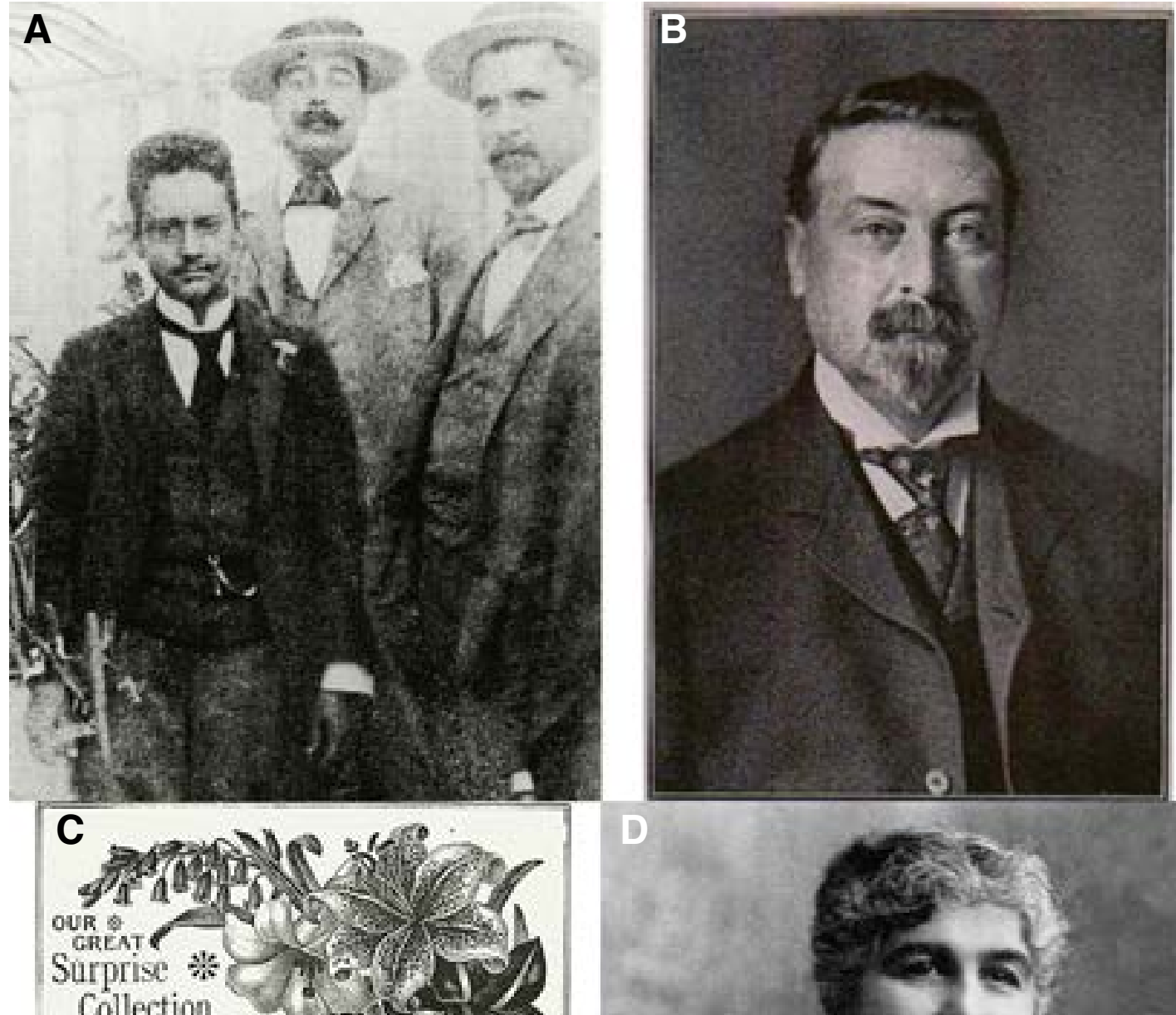

Collection.

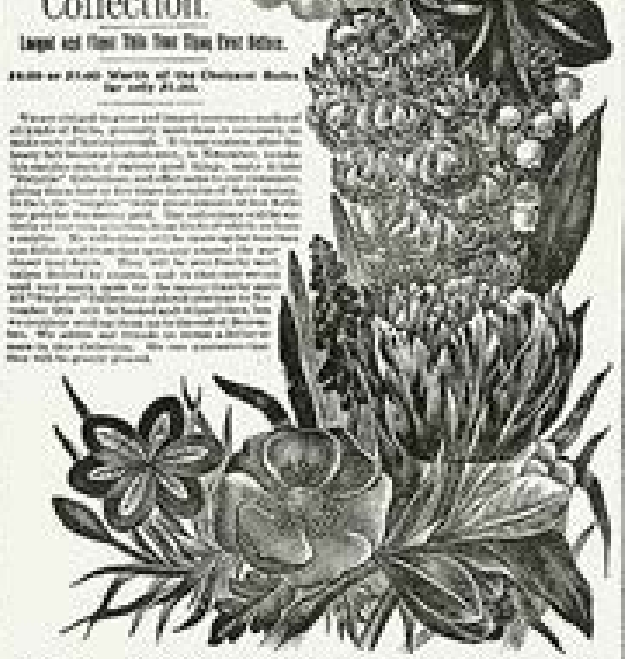

Medres JOHN LEWIS CIILDS, Floral Park. N. Y,

FIGURE 15. A — Carlos (Karl) Werckle (on the right) with Anastasio Alfaro (on the left) and John Lewis Child (center) in 1893.

B - John Lewis Childs. C — Advertisement of Floral Park. D — Doña Amparo de Zeledón. 

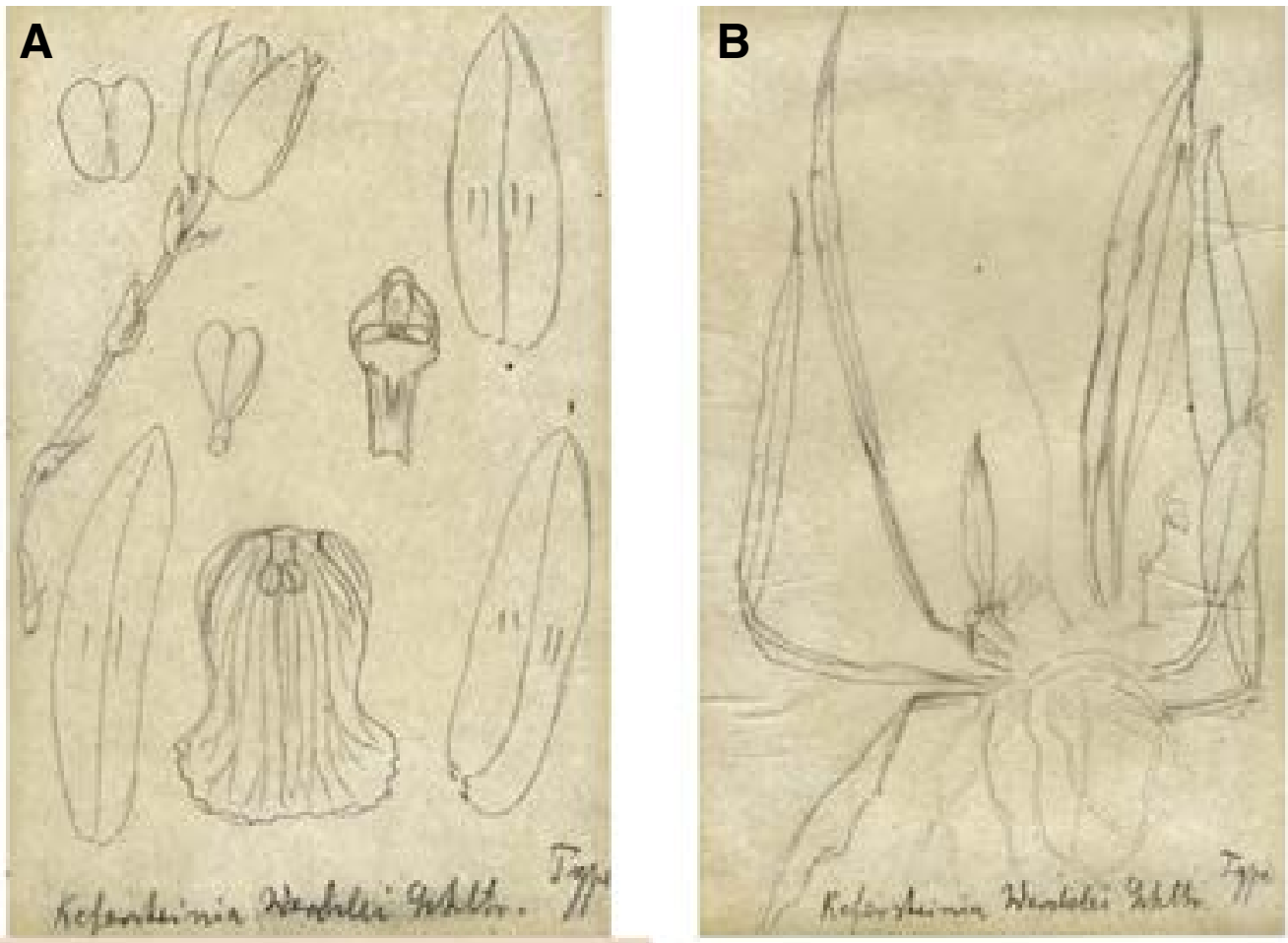

C

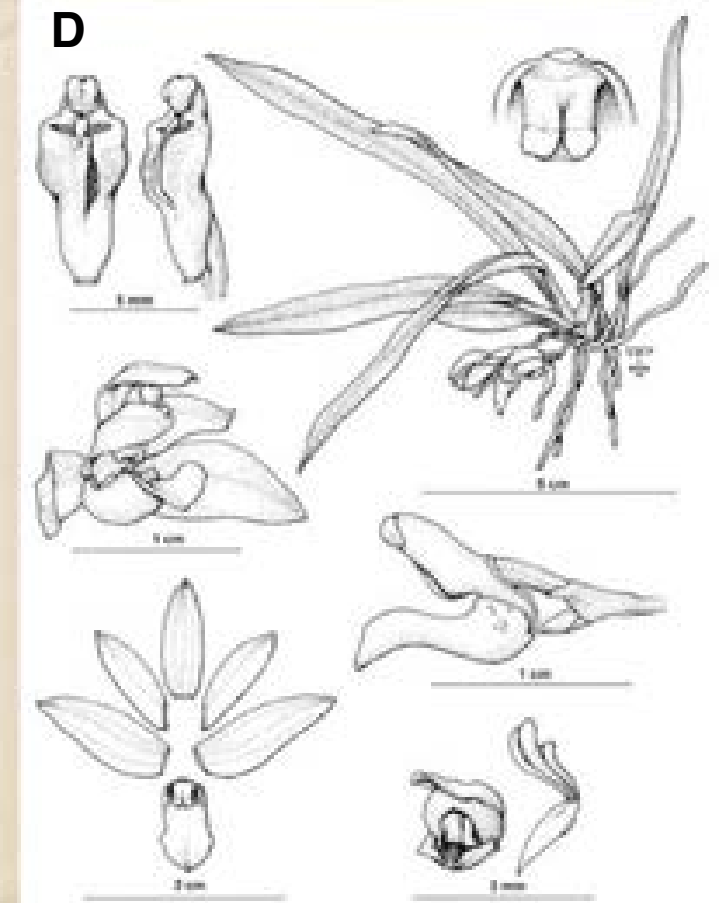

FIGURE 16. A, B - Copies of Schlechter's original sketches of the type of Kefersteinia warcklei. B - An unpublished plate from Reichenbach's Xenia Orchidacea, illustrating K. wercklei (as Zygopetalum umbonatum). C - A modern illustration of K. wercklei, from Pupulin 2001. 


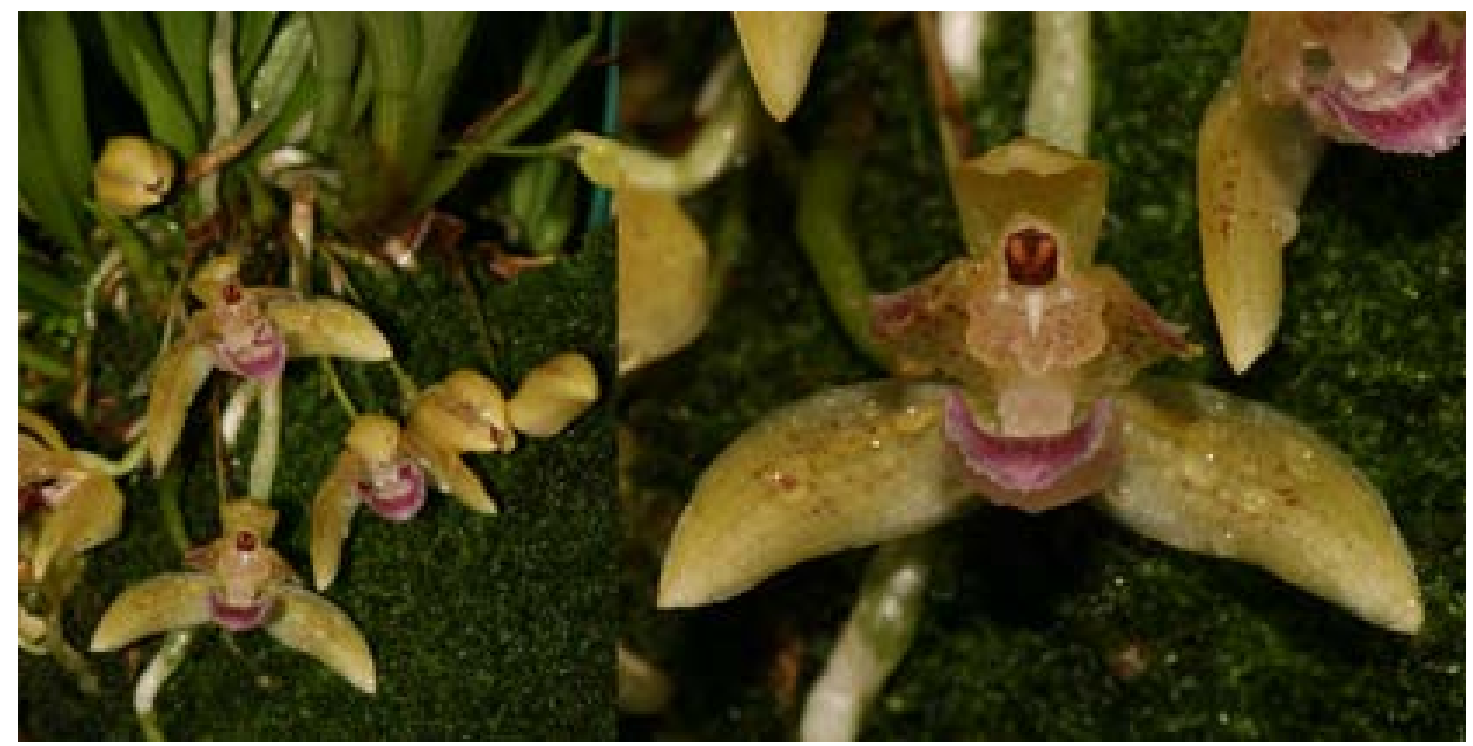

FIGURE 17. Kefersteinia wercklei, habit and flower.

from Costa Rica and based on recommendation of Alfred Brade, head-gardener of the town San Jose, she allowed Wercklé and Adolfo Tonduz to select interesting material for Schlechter. She herself also paid Wercklé for his work and sent him on collecting trips. Wercklé and Tonduz together collected almost $15^{\prime} 000$ specimens for the herbarium of the Museo Nacional, although Wercklé's way to collect plant material was not state of the art: ".....his favourite way of preserving an interesting plant was to roll it into a bundle and stuff it in a pocket, where it remained indefinitely, it is thus only too easy sometimes to recognize in the herbarium his specimens, without even looking at the label" (Standley 1926). The plants they collected alive went first to the garden of Doña Amparo and where subsequently prepared by Tonduz for the herbarium. Based on Wercklé's collections, Schlechter described later 4 new orchid genera and more than 80 new species. Besides orchids, Wercklé was also very interested in ferns and bromeliads, he had an extremely good trained eye for them, and collected hundreds of species studied and described later by Hermann Christ in Basel, Switzerland. In 1906 the National Society for Agriculture sent Wercklé to southern Colombia, obviously he collected several Cacti and Bromeliads and took them home to Costa Rica. In 1911, Wercklé was employed for a few months by the herbarium of the Museo Nacional. Beside all those activities, Wercklé seems to have had his own "jardineria" first in Cartago and later in San Jose. He published a series of articles, the first one in 1901 in "Torreya", and in 1913 "the first scientific article ever written in Costa Rica about the orchids of this country" (Ossenbach 2003) in "Boletin do Fomento". His main work was "La Subregion Fitogeografica Costarricense" in 1909. Some of his articles were published in German periodicals like "Monatsschrift für Kakteenkunde" and "Der Tropenpflanzer".

From a letter of Henry Nehrling to Theodor Luqueer Mead from December 1918 we learn that Wercklé was also collecting and selling Bromeliads. Nehrling (1853-1929) started "Nehrling's Tropical Garden and Arboretum" in 1917 in Naples, Florida and was in close contact with Mead (1852-1936) who had a collection of tropical plants - including orchids - in Oviedo, Florida. Nehrling wrote to Mead: "Do you know a good book on the flora of Costa Rica? Carlos Werckle wrote me some time ago that he has discovered a number of new Bromeliads rivalling in beauty with Caraguata zahnii, Massangea musaica and others and still very distinct. He intends to send me a fine collection of the Costa Rican species, about 300 distinct kinds. He says that the center of distribution of Bromeliads in Costa Rica is found in the mountains around Cartago. Says that his wife "is in many respects 
an ideal, but she is extremely nervous, and not at all healthy". In another letter from November 1925 we read: "Carlos Werckle, an old friend of mine and now dead, discovered some most beautiful new species in the mountains of Costa Rica. They all have been described by Dr. Mez (Professor at the University of Königsberg). He sent me a consignment about 6 years ago - 50 species, mostly new. They came as far as Jacksonville but were returned by the man who acted for the Federal Plant Board and Werckle never could be induced to send me another lot, even after I had sent him special permits". Wercklé was not married, the remark about "his wife" is wrong, most probably he talked about his sister.

In 1922 Oakes Ames was looking for a collector in Central America and contacted Charles Lankester in Costa Rica in order to get his opinion about Wercklé, Lankester's answer from $11^{\text {th }}$ of October 1922 was very clear: "Wercklé is a dipsomaniac, an appalling wreck of a fine intelligence, but has still some good local knowledge and might be of use yet" (Ossenbach 2003). In his later years Wercklé started to develop a passion for alcohol, he drank and this was most probably the reason for his early death on $24^{\text {th }}$ of November 1924 .

Kefersteinia wercklei (Fig. 16D, 17) was described in 1923 by Rudolf Schlechter in "Feddes Repertorium, Beihefte" based on a plant collected by Wercklé in June 1921 near La Palma. The article was dedicated to Doña Amparo de Zeledón as "Orchidaceae Amparoanae" (Schlechter 1923), the specimens were collected by Tonduz and Wercklé, cultivated first in the garden of Doña Amparo, dried by Tonduz and sent in several consignments to Schlechter. Again, the type specimen of Kefersteinia wercklei was lost in 1943, but a copy of Schlechter's drawing and the type specimen is in the AMES herbarium in Harvard (Fig. 16A, 16B). In 1944 Charles Schweinfurth described in "American Orchid Society Bulletin" Chondrorhyncha pusilla from Peru and recombined in a footnote the "allied" species Kefersteinia wercklei Schltr. to Chondrorhyncha wercklei (Schltr.) C. Schweinfurth (Schweinfurth 1944). The part about the subtribe Huntleyinae for the $3^{\text {rd }}$ edition of Schlechters "Die Orchideen" was written by Karlheinz Senghas, Helga Dietrich and Günter Gerlach. The authors defined the new section Umbonata for the species-group around Kefersteinia costaricensis and included also Kefersteinia wercklei. They also mentioned the unpublished taxon Kefersteinia umbonata as synonym of Kefersteinia wercklei (Senghas et al. 1992). Kefersteinia umbonata is based on a drawing by Endrés named Zygopetalum umbonatum in Reichenbach;s herbarium in Vienna (W-R no.336). Of the same drawing a lithograph was made, planned to be published in "Xenia Orchidacea" and named Zygopetalum umbonatum (Fig. 16c). On a second sheet (W-R no.34708) we find the handwritten description as "Zygopetalum (near Kefersteinia)" and a drawing of the flower parts by Endrés. The binomial Kefersteinia umbonata is not mentioned on any of the sheets of the Endrés-material in Vienna. In the German journal "Journal für den Orchideenfreund" of 2003 Dariusz Szlachetko described the new genus Senghasia based on the section Umbonata of Kefersteinia with 12 species (Szlachetko 2003). He recombined Kefersteinia wercklei to Senghasia wercklei. The genus is named after Karlheinz Senghas, orchidologist, longtime-director at the Botanical Garden Heidelberg and co-author of the third edition of Rudolf Schlechters "Die Orchideen".

\section{LiTERATURE CITED}

Allen, P. H. 1952. Telipogon endresianum Kraenzlin. Orchid Journal (A.D.Hawkes) 1: 292-293

Ames, O. \& C. Schweinfurth. 1930. New or noteworthy Orchids. Schedul. Orch. 10: 1-112.

Anonymous. 1897a. Gardeners' Chronicle ser.3,21: 241.

Anonymous. 1897b. Orchid Review 5:109

Anonymous. 1923. Berichte der Schweizerischen Botanischen Gesellschaft 32: IX-X.

Barringer, K. 1984. Typification of Schlechter's Costa Rican Orchidaceae, types collected by A. Brenes. Fieldiana Bot. new series 17: 1-24.

Beauverd, G. 1922. M. Adolphe Tonduz. Bulletin de la Societe Botanique de Geneve, ser.2, 14: 12-13.

Bentham, G. 1881. Notes on Orchideae. Journal of the Linnean Society 18(110): 337.

Bogarín, D \& F. Pupulin. 2007. El genero Campylocentrum en Costa Rica: algunas preguntas criticas y unas pocas respuestas. The genus Campylocentrum in Costa Rica: some critical questions and a few answers. Proc. of the Second Scientific Conference on Andean Orchids: 12.

Bogarín, D. 2010. Revisión taxonómica del género Campylocentrum (Orchidaceae: Angraecinae) en Costa Rica. Dissertation. Universidad de Costa Rica. Pp. 39-122.

Bogarín, D. \& F. Pupulin. 2010. The genus Campylocentrum 
(Angraecinae) in Costa Rica: a revision. Harvard Papers in Botany 15(2): 353-414.

Cogniaux, A. C. 1897. Orchidees nouvelles ou recement introduites. Chronique Orchidéenne 1(4): 32.

Dressler, R. L. 1993. Field Guide to the Orchids of Costa Rica and Panama. Comstock Publishing.

Gómez, L. D. 1977. Contribuciones a la pteridologia Costarricense XII: Hermann Christ, su vida, obra e influencia en la botanica nacional. Brenesia 12-13: 57-59.

Gómez, L. D. 1978. Contribuciones a la pteridologia Costarricense XII: Carlos Wercklé. Brenesia 14-15: 361-393.

Häsler, B. \& T. W. Baumann. 2000. Henri Pittier, 18571950, Leben und Werk eines Schweizer Naturforschers in den Neotropen. Reinhardt Verlag Basel.

Harding, P. 2008. Huntleyas and related orchids. Timber Press, Oregon.

Jiménez, J. A. 1945. Un Costarricense ilustre. Revista del Instituto de defensa del Café de Costa Rica 15(131): 523-525.

Königer, W. 2007. Oncidium, eine Monographie, 3. Verlag Helga Königer. Pp. 89-92.

Kränzlin, F. 1919. Beiträge zur Kenntnis der Gattung Telipogon H.B.K. Annalen des Naturhistorischen Hofmuseums Wien 33: 29-31.

Kränzlin, F. 1922. Orchidaceae-Monandrae, Tribus Oncidiinae - Odontoglosseae Pars II. Das Pflanzenreich IV.50(2): 199.

León, J. 1945. Notas sobre la labor botanica de don Alberto M. Brenes. Revista del Instituto de defensa del Café de Costa Rica 15(131): 526-527.

Lobo, S. 2004. Tipos de Orquidaceas Brenesianas, descritas por R.Schlechter, en el herbario nacional de Costa Rica. Lankesteriana 4(1): 37-45.

López, G.D. 2009. La Nación (Costa Rica). 8 March 2009.

Luer, C. A. 1986. Thesaurus Masdevalliarum 7: sub. t.13.

Luer, C. A. 2001. Icones Pleurothallidinarum 22. Monographs in Systematic Botany from the Missouri Botanical Garden, 86 :769-770.

Mansfeld, R. 1931. Bluetenanalysen neuer Orchideen, II. Mittelamerikanische Orchideen. Repertorium Specierum Novarum Regni Vegetabilis Beihefte 59(2): t.74; 78, fig. 295; 309.

Mirenda, T. 2010. Telipogons, the ultimate orchids. Orchids (West Palm Beach) 79: 552-554

Mora de Retana, D. E. \& J. T. Atwood. 1993a. Masdevallia tonduzii Woolward. Sub. pl. 1558 in: Orchids of Costa Rica, part 3. Icones Plantarum Tropicarum 16.

Mora de Retana, D. E. \& J. T. Atwood. 1993b. Oncidium luteum Rolfe. Sub. pl. 1572 in: Orchids of Costa Rica, part 3. Icones Plantarum Tropicarum 16.

Ortiz, F. 2002. Perfil de Don Alberto Brenes Mora. Brenesia 57-58: 19-24.
Ossenbach, C. 2003. History of Orchids in Central America, from prehispanic times to the new millennium 2: 131132, 135. Unpublished manuscript.

Ossenbach, C. 2006. Orchids in Costa Rica, part I : The era of Rudolf Schlechter. Orchids (West Palm Beach) 75: 38-47.

Ossenbach, C. 2008. Adolphe Tonduz (1862-1921). Revista Biocenosis 21(1-2): 13-19.

Ossenbach, C. 2009. Orchids and Orchidology in Central America: 500 years of history. Lankesteriana 9(1-2): $149-157$.

Pfau, R. 1883a. The climate of Central America, orchid culture. Gardeners' Chronicle, new ser. 20: 558-560.

Pfau, R. 1883b. Hints on the culture of some rare Central American orchids. Gardeners' Chronicle, new ser 20: 658.

Pfau, R. 1883c. Cypripedium caudatum. Gardeners' Chronicle, new ser. 20: 722.

Pfau, R. 1884a. Cypripedium roebbeleni. Gardeners' Chronicle, new ser. 21: 16 .

Pfau, R. 1884b. Trichocentrum pfavii. Gardeners' Chronicle, new ser. 21: 50 .

Pfau, R. 1894. Notes on the fertilisation of orchids in the tropics. Orchid Review 2: 295-296.

Pfau, R. 1895. New, rare, and beautiful orchids of Costa Rica and how they grow at home. San José, Costa Rica. Pp. 1-12.

Pfau, R. 1896. Costa Rica and its Orchids. Gardeners' Chronicle, ser.3, 19: 548-549.

Pittier, H. 1922. Gazette de Lausanne 154(55): 2 (24.2.1922).

Pupulin, F. 1995. A revision of the genus Trichocentrum (Oncidiinae). Lindleyana 10(3): 183-210.

Pupulin, F. 1997. The Trichocentrum pfavii group. Caesiana 8: $1-14$.

Pupulin, F. 2001. Miscellaneous new taxa in neotropical Orchidaceae. Selbyana 22(1): 14-26.

Pupulin, F. 2005. Vanishing Beauty. Native Costa Rican Orchids. Vol. 1: Acianthera-Kegeliella. Editorial de la Universidad de Costa Rica, San José. P. XXI.

Pupulin, F. 2010. Orchidaceae werckleanae: typification of Costa Rican orchid species described from collections by K.Wercklé. Botanical Journal of the Linnean Society 163: 111-154.

Pupulin, F. \& D. E. Mora de Retana.1994. A revision of the Costa Rican species of Trichocentrum. Selbyana 15(2): 87-103.

Reichenbach, H.G. 1881. New garden plants: Trichocentrum pfavii, Cirrhopetalum abbreviatum, Cirrhopetalum trigonopus. Gardeners' Chronicle, new ser. 16: 70.

Reichenbach, H.G. 1883. New garden plants: Calanthe Lentiginosa, Trichocentrum pfavii, Trichocentrum pfavii zonale, Odontoglossum hebraicum lineoligerum, 
Dendrobium chrysanthum anophthalmum. Gardeners' Chronicle, new ser. 19: 44.

Rolfe, R. A. 1893. New Orchids: Decade 6. Bulletin of Miscellaneous Information (Kew) 1893: 172.

Salazar Rodríguez, A.H. 2009. Alberto Manuel Brenes, el naturalista. Editorial de la Universidad de Costa Rica, San José.

Sánchez Porras, R. 2002. Pionero de la biologia en Costa Rica, Manuel Alberto Brenes. Brenesia 57-58: 7-18.

Schlechter, R. 1910. Orchidaceae novae et criticae, Decas XI. Repertorium Specierum Novarum Regni Vegetabilis 9: 30, 293.

Schlechter, R. 1923. Beiträge zur Orchideenkunde von Zentralamerika. Repertorium Specierum Novarum Regni Vegetabilis Beihefte 19: 1-75; 157; 268-269.

Schweinfurth, C. 1944. A genus and species unrecorded for Peru. American Orchid Society Bulletin 12(11): 384-385.

Senghas, K., H. Dietrich \& G. Gerlach. 1992. 689. Chaubardiella. In: R.Schlechter, Die Orchideen Ed.3, 1B(26): 1646-1647.

Standley, P. C. 1926. Carlos Wercklé. Science 63(1626): 221-223.
Stevens, F. B. 1977. Epidendrum pfavii (Rolfe). Orchid Review 85(1008): 176-177.

Szlachetko, D. L. 2003. Senghasia, eine neue Gattung der Zygopetaleae. Journal für den Orchideenfreund 10(4): 332-344.

Todzia, C. A. 1980. Revision of the Costa Rican species of Campylocentrum. Brenesia 18: 117-136.

Wercklé, C. 1903. Gemüsepflanzen von Costarica. Der Tropenpflanzer 7: 425-439.

Wercklé, C. 1904. Heteromorphismus epiphytischer Cereen. Monatsschrift für Kakteenkunde 14: 62-63.

Wercklé, C. 1905. Cactaceae in Costa Rica. Monatsschrift für Kakteenkunde 15: 3-4, 165-168, 179-181.

Wercklé, C. 1907. Cacteen in Zentral-Columbien. Monatsschrift für Kakteenkunde 17: 18-20.

Williams, L. 1956. Enumeration of Orchidaceae of Central America, British Honduras and Panama. Ceiba 5(1): 195.

Woolward, F. H. 1906. Masdevallia tonduzii spec. nov. Bulletin de l'Herbier Boissier ser.2,6:82. 
LANKESTERIANA 